IZA DP No. 8226

Migration, Education and the Gender Gap in Labour Force Participation

Ithom Abdulloev

Ira N. Gang

Myeong-Su Yun

May 2014 


\title{
Migration, Education and the Gender Gap in Labour Force Participation
}

\author{
Ilhom Abdulloev \\ Rutgers University, \\ OSI and IZA \\ Ira N. Gang \\ Rutgers University, \\ CReAM, IOS and IZA \\ Myeong-Su Yun \\ Tulane University \\ and IZA
}
Discussion Paper No. 8226
May 2014

IZA

P.O. Box 7240

53072 Bonn

Germany

Phone: +49-228-3894-0

Fax: +49-228-3894-180

E-mail: iza@iza.org

\begin{abstract}
Any opinions expressed here are those of the author(s) and not those of IZA. Research published in this series may include views on policy, but the institute itself takes no institutional policy positions. The IZA research network is committed to the IZA Guiding Principles of Research Integrity.

The Institute for the Study of Labor (IZA) in Bonn is a local and virtual international research center and a place of communication between science, politics and business. IZA is an independent nonprofit organization supported by Deutsche Post Foundation. The center is associated with the University of Bonn and offers a stimulating research environment through its international network, workshops and conferences, data service, project support, research visits and doctoral program. IZA engages in (i) original and internationally competitive research in all fields of labor economics, (ii) development of policy concepts, and (iii) dissemination of research results and concepts to the interested public.
\end{abstract}

IZA Discussion Papers often represent preliminary work and are circulated to encourage discussion. Citation of such a paper should account for its provisional character. A revised version may be available directly from the author. 
IZA Discussion Paper No. 8226

May 2014

\title{
ABSTRACT
}

\section{Migration, Education and the Gender Gap in Labour Force Participation}

\begin{abstract}
Women who want to work often face many more hurdles than men. This is true in Tajikistan where there is a large gender gap in labour force participation. We highlight the role of two factors - international migration and education - on the labour force participation decision and its gender gap. Using probit and decomposition analysis, our investigation shows that education and migration have a significant association with the gender gap in labour force participation in Tajikistan. International emigration from Tajikistan, in which approximately $93.5 \%$ of the participants are men, reduces labour force participation by men domestically; increased female education, especially at the university and vocational level, increases female participation. Both women acquiring greater access to education and men increasing their migration abroad contribute to reducing the gender gap.
\end{abstract}

JEL Classification: J01, J16, O15

Keywords: migration, education, gender gap, labour force participation, Tajikistan

Corresponding author:

Myeong-Su Yun

Department of Economics

Tulane University

206 Tilton Hall

New Orleans LA 70118

USA

E-mail: msyun@tulane.edu 


\section{Introduction}

Men and women often differ in their behaviours and in the constraints they face, resulting in gender gaps in economic outcomes. We study the roles migration and education play in labour force participation (LFP) decisions made by men and women in the migrants’ source country. ${ }^{1}$

Studies on the gender gap in LFP delineate a range of potentially responsible domestic factors (Mammen and Paxson, 2000; Klasen and Pieters, 2012; Cunningham, 2001; Priebe, 2011; Klasen, 1999; Dollar and Gatti, 1999; Goldin, 1995; Semyonov, 1980). Most blameable not only in employment but all walks of economic and social life is lower investment in female education and health care (Klasen, 1999; Dollar and Gatti, 1999). Existing social stigmas, resource constraints, institutions and discrimination all contribute to lower educational investment and attainment for women. Often parents allocate family resources to sons because in many societies after marriage the daughter leaves the household while the son remains. Lower investment in daughters leads to lower educational attainment, reducing earnings (Becker, 1991; Mincer, 1974; Neumark and McLennan, 1995) and lowered women's wages, job opportunities, and LFP. This can be seen most vividly in rural areas, where women face greater obstacles than urban women in obtaining education (UNESCO, 1964). Educational facilities are more accessible in urban areas and while men may venture to urban areas for education, women do so with less frequency (UNESCO, 1964).

With weak anti-discriminatory regulations, employers may pay women lower wages anticipating childbirth and childcare leaves; married women might choose to stay at home,

\footnotetext{
${ }^{1}$ Formally, participation includes the employed and unemployed. However, most studies of labour supply do not count the unemployed in the definition of participation even though they still use the term "participation”. We follow this convention.
} 
looking after their children and doing housework. Where there is a socially constructed stigma against women working in paid labour outside the home, low female LFP is also a response to the movement of production from households and family farms to a larger market, leaving women outside the production process (Goldin, 1995). Country-specific characteristics such as culture, income inequality and occupational segregation by gender also influence female LFP (Semyonov, 1980). Financial crises also worsen the gender gap in employment (Signorelli, Choudhry and Marelli, 2012).

Migrant remittances can affect the labour supply decisions of migrants' relatives back in their home country. Remittances have the same effect as non-wage income, reducing the work hours of family members if leisure is a normal good (Killingsworth and Heckman, 1987). Thus, remittances might raise individual reservation wages higher than market wages so migrant family members would choose not to work.

The literature finds the scale of the negative effect migration may have on LFP is different for men and women (Rodriguez and Tiongson, 2001; Nguen and Purnamasari, 2011; Amuedo-Dorantes and Pozo, 2006; Cabegin, 2006; Acosta, 2006). Why do we observe such different responses to migration by men and women? If migration is male-dominated men in migrants' families after learning about high earning opportunities abroad through their migrant relatives might seek to migrate. Therefore, men in migration experienced families are more likely than women to leave their jobs for temporary unemployment and preparation for future migration, a type of demonstration effect. ${ }^{2}$ Indeed, a recent study by Abdulloev (2013) finds migrants' working relatives in the source country, after learning about migrants' higher earnings

\footnotetext{
${ }^{2}$ If migration is dominated by women, the demonstration effect will be larger for women relative to men.
} 
either directly from migrants or from observing the size of remittances, have reported being dissatisfied with their jobs. If job quits and job satisfaction are negatively correlated, then migrants' family members might be more likely to quit their jobs in anticipation of joining their migrant relatives by moving abroad. Another group of studies argues that migration economically empowers the wives of migrants, increasing their LFP (Hondagneu-Sotelo, 1992; Paris et.al., 2005; Hadi, 2001).

In the next section, we discuss the economic background of Tajikistan, a small Central Asian, former Soviet and developing country with good wide-spread education, large numbers working abroad and a gender gap in LFP. Remittances sent by Tajikistan's migrants made this country one of the most remittance dependent countries in the world since 2009. Such conditions make Tajikistan useful for studying the impact of migration and education on the gender gap in LFP. Section three discusses the variables and data used in our empirical analysis. Section four provides probit estimation results of the effects of migration on LFP by gender. The following section discusses the results of decomposing the effects of different individual and family characteristics, as well as migration, on the gender gap in LFP. The sixth section concludes.

\section{Tajikistan's Economic Background}

Tajikistan experienced a severe economic downturn after the collapse of the Soviet Union in 1991. The breakdown of the USSR ruptured economic ties among enterprises in former Soviet republics, while rivalries among regional clans became the foundation of a civil war lasting from 1992 until 1997. By the end of the war GDP had shrunk to 35\% of its 1990 level and inflation was at $65.2 \%$ (World Bank, 2011).

New economic policies were implemented soon after the peace accord and formation of 
the joint government in 1997. Over the 2001-2010 period annual real GDP grew at an 8.8\% average rate; average annual inflation was 20.7\% (World Bank, 2013). Despite these positive achievements, Tajikistan remains economically far behind other countries of the former USSR with the highest poverty rate and lowest GDP per capita. GDP per capita was US\$820 in 2010 (for comparison, in the Russian Federation - US $\$ 10,481$ ); poverty by the headcount ratio was 46.7\% in 2009 (World Bank, 2013). Average monthly wages were US\$82.90 in 2010; about 8.5 times lower than those of the Russian Federation (Statistical Committee of CIS, 2011). In traditional sectors of economy -- agriculture, forestry and fisheries, which together employ $50 \%$ of Tajikistan's working population, monthly wages were US\$23.60, $\$ 39.10$ and $\$ 41.60$, respectively (Statistical Agency of Tajikistan, 2011).

With large income and wage differentials between Tajikistan and other former Soviet countries came significant emigration of one-fifth of its working population. In turn, Tajikistan became one of the world's most remittance-dependent countries: remittances reached $35.1 \%$ of GDP in 2009 (World Bank, 2011). Data from the 2007 World Bank Living Standard Measurement Survey on Tajikistan (TLSS 2007) show that most (95.3\%) of its migrants go to Russia, are predominantly men (93.5\%) from rural areas (76.4\% of all migrants), are ethnically Tajiks (81.4\% of all migrants), and have only secondary education (64.36\% with no university or other post-secondary school training). $74.2 \%$ of Tajikistan's migrants remitted in cash only, $1 \%$ remitted in-kind only, and 6.6\% remitted both in-kind and in cash.

During the Soviet period, gender relations in Tajikistan were guided by directives from Moscow on women's emancipation and involvement in production. There have been great achievements in liberating and attracting women into decision making processes at regional and national levels, and increased education among women. Tajikistan still follows non- 
discriminatory policies against women. It has ratified a number of international conventions protecting women rights; among them the Convention for Eliminating All Forms of Discrimination against Women. Legal protections of women's rights are also reflected in its Constitution, as well as national laws. The Tajik Government also implements plans and programs directed towards increasing female participation and providing equal rights and opportunities with men (Safarova, et al., 2007).

Despite the existence of state non-discrimination policies and programs directed towards gender equality, female LFP in Tajikistan is low. In 2007, the level of economic activity of women of age 14 and above was $31.1 \%$ versus $58.1 \%$ for men. The gap is narrower in the $15-24$ age range: female LFP was 22.8\%, while male participation was 31.8\% (Statistical Agency of Tajikistan, 2010). A recent study by Blunch (2010) confirms the presence of a large gender earnings gap in the country in favour of men.

Tajikistan's women also face occupational segregation, working in low-paid sectors, such as education, health care and agriculture with salaries 4-8 times lower than in industries in which men predominate (Shahriari, Danzer, Giovarelli, and Undeland, 2009). The TLSS 2007 (see Table 1) shows that the women are underrepresented in managerial occupations, such as legislators, senior officials and managers, $1.6 \%$ of working women versus to $4.6 \%$ of working men; in crafts and plant and machine operators $4.8 \%$ and $0.5 \%$ versus $18.7 \%$ and $11.6 \%$ for men, respectively. The major employer of women remains the agricultural sector where they are two times more represented than men: $47.2 \%$ of working women versus $23.5 \%$ for working men.

The official data on the distribution of employees and salaries by sectors of the economy and gender are reported in Table 2. According to this table women are employed less in all material production sectors of Tajikistan's economy. Tajikistan's women are employed more than 
men in health, and have almost equal employment with men in culture, arts and science. Furthermore, on average for all sectors, women receive salaries which are 158 Somoni (US\$46) less than men. The highest wage differential is in public management and crediting sectors, where men receive salaries which are 342 Somoni (US\$99) more than women. Almost equal salaries between men and women are in the trade sector. The only sector where women have a significant advantage in salaries is in housing utilities and consumer services sectors, where their salaries are on average 13 Somoni (US\$4) larger. In short, women in Tajikistan face segregation in occupation and industry, and receive significantly lower compensation.

\section{Data}

Tajikistan provides a good case for studying the roles of massive emigration and education on domestic labour supply decisions. Since independence in 1991, large numbers of Tajiks have emigrated and returned, mainly to Russia. This has made Tajikistan the subject of several useful data collection efforts. We use the data from the 2007 World Bank Living Standard Measurement Survey on Tajikistan (TLSS 2007). The survey asks questions on both individual qualities including information about migration experience, and household economic conditions. The survey was conducted during September and October 2007, with many households revisited in November.

Our sample includes men and women in their core economically active ages from 25 to 55. We look at the employment decisions of those who were in households that were revisited in November 2007. Our whole sample size is 10,103 people: 4,662 men and 5,441 women. 76.1\% of respondents in our sample, or 6,926 people, live in rural areas (Rural): 3,244 men and 3,682 women. The respondents from urban areas make-up $23.9 \%$ of the whole sample (Urban), or 
3,177 people: 1,418 are men and 1,759 are women. $7.8 \%$ of respondents live the capital of Tajikistan - Dushanbe (RegionD1), 29.4\% live in Sogd province (the northern part; RegionD2), 36.7\% live in Khatlon province (the south-eastern part; RegionD3), 23.3\% live in Regions of Republican Subordination (around the capital, and further to its east; RegionD4), and 2.8\% live in the highest mountainous (eastern) part of Tajikistan, the Badakhshan area (RegionD5). Variable definitions are given in Table 3; summary statistics by gender and rural-urban divisions are reported in Table 4.

Our main variable of interest is $L F P$ which takes a value of 1 if a respondent worked in the last 14 days including occasional work and zero otherwise. 56.4\% of whole sample were employed in last 14 days, the employment rate in rural is larger than in urban areas, 57.3\% versus $53.6 \%$, respectively. The employment rate among women is significantly lower than that of men: in the whole sample, $77.2 \%$ of men and $37.5 \%$ of women worked; while, in rural areas, the employment of men is $77.4 \%$ and that of women is $38.7 \%$, and in urban areas, the employment of men is $76.5 \%$ and of women is smaller, at $33.9 \%$. Higher women employment rates in rural areas might be driven by two major factors. Firstly, migration is higher in rural areas, and since it is male dominated, women remaining in these areas have to work in order to compensate for the absence of their male relatives. Secondly, farming, forestry and fishing sectors providing almost $50 \%$ of jobs in Tajikistan are concentrated in rural areas and have relatively more female employment. Women (female) are slightly over-represented in our sample, probably because Tajikistan's large external migration is male dominated: women constitute $52.4 \%$ of the whole sample, $52 \%$ in the rural sample and $53.6 \%$ in the urban sample. The dummy variables for age categories show the decreasing relationship between the number of people and age. The majority of respondents are 25 to 29, 25.7\% of the whole sample, $26.5 \%$ of 
the rural sample and $23 \%$ of the urban sample. This is not surprising; Tajikistan's population is overwhelmingly young.

We aim to capture the link between migration and the decision to work (LFP) using two dummy variables. The first dummy variable Mig_Exp defines individual migration experience. In our sample, 5.5\% of respondents were migrants in last 12 months, predominantly men (10.9\% of the male sample versus $0.7 \%$ of the female sample) and from rural areas (5.8\% of the rural sample respondents were migrants or $11.4 \%$ of rural men). Respondents from urban areas have been less involved in migration, $4.6 \%$ were migrants in last 12 months, or $9 \%$ of the urban male population.

The second migration variable, Mig_HH, defines whether an individual has a migrant relative who currently lives in another country. $12.9 \%$ of respondents in the whole sample have at least one relative who currently lives in another country. Since the majority of Tajikistan's migrants are from the rural areas, respondents from rural areas are more likely to have migrant relatives than respondents from urban areas, $14.4 \%$ of rural versus $8.3 \%$ of urban respondents. Because migrants are predominantly men, households with current migrants have more female members: in the whole sample, women with current migrants constitute $15.2 \%$ while only $10.5 \%$ of men have a current migrant relative. These numbers are higher for the rural sample, $17 \%$ of women and $11.5 \%$ of men in these areas have current migrant relatives. However they are lower for the urban sample, $9.4 \%$ of women and $6.9 \%$ of men have current migrant relatives.

The education system in Tajikistan consists of pre-school education, general education, and professional education. Pre-school education is compulsory, however parents have the option of sending their children to pre-school organizations or educating them at home. General education is divided into three parts: primary, basic and secondary education. Tajik law requires 
all children at age 7 to attend school, and guarantees their education until age 16. Inherited from the Soviet era, this system ensures high school attendance rates.

Professional (post-secondary) education is wide-spread in Tajikistan, with $25.1 \%$ having what is referred to as a professional education: $14.2 \%$ graduating from special and technical schools (EducVoc) and 10.9\% graduated from universities (EducHigh). The majority of respondents graduated from secondary general schools (EducGen), 56.5\%. 18.4\% of respondents have a primary education (EducPrimary). There is a large difference in educational attainment between men and women in Tajikistan. On average women are more likely to have primary or secondary education than men: $24.7 \%$ of women and $11.5 \%$ of men have primary education and $61.6 \%$ of women and $50.9 \%$ of men have a secondary general education. However, more men have professional education than women: $20.8 \%$ of men and $8.2 \%$ of women have education from special and technical schools, while $16.8 \%$ of men and 5.5\% of women have professional degrees from universities.

On average respondents from rural areas are more likely to have non-professional education, i.e. education limited to primary (19.5\%) or secondary (59.4\%) general education. These numbers are correspondingly $14.9 \%$ and $47.2 \%$ for the urban sample. Living in urban areas further increases opportunities to acquire professional education, with $18.6 \%$ of the urban population having professional education from special and technical schools and 19.3\% from universities. The corresponding numbers for rural population are $12.8 \%$ and $8.2 \%$. More women in rural areas lack professional education than women living in urban areas: $26.3 \%$ and $64.6 \%$ of rural women have education from primary and secondary general schools, while $19.9 \%$ and $52.1 \%$ of urban women have such education, respectively. Since professional schools are mainly concentrated in urban areas in Tajikistan, women living in these areas have a greater chance of 
obtaining professional education than women in rural areas: $15.3 \%$ and $12.7 \%$ of women in urban areas have professional education from special and technical schools and universities, respectively. The corresponding numbers for women in rural areas are 5.9\% and 3.2\%.

A quarter of respondents in our sample are heads of households (Head), 46.7\% of men and $5.8 \%$ of women. The number of household heads is lower in the rural sample, since families are larger in rural areas of Tajikistan and living in rural areas increases chances of migration for men including household heads. Furthermore, female headed households are more likely to be living in urban areas. Most of the respondents in our sample are married (Married), 87.9\%. Men are more likely to be married, $92.3 \%$ of men in whole or rural samples, and $92.2 \%$ of men in urban sample are married. Marriage rates are lower for women in urban areas: $80.5 \%$ of women in urban areas and $85 \%$ of women in rural areas married.

The majority in our sample are of Tajik ethnicity (Tajik): 75.3\% of whole sample, $74.9 \%$ of all men and $75.6 \%$ of all women. Relatively more Tajiks are from rural areas: $84 \%$ and $72.6 \%$ live in rural and urban areas, respectively. Most of non-Tajiks are Uzbek. Other minority ethnicities include Russian, Kyrgyz, Tartar, and Turkmen.

Households in our sample have an average size (HHSize) of 8.6 people. Households in rural areas are relatively larger than household in urban areas: on average, rural households have 9 people, while urban household have 7.6 members. Decomposition into age categories shows rural households have more children and elders: on average, there are 1.4 children younger than 6 (Child6), 2.4 children between 6-17 (Child6_18), and 0.4 elderly 65 or older (Elder65) in rural areas, while 1.2 children with age of less than 6,2 children with 6-17 ages, and 0.2 elders in urban areas. 
On average monthly non-wage income (OtherIncom1000) is 533 Somoni, generated by households and including wages of other household members, remittances, scholarships, transfers, social assistance, income from rent and farming, and other income received by all household members. Women have more non-wage income than men in all three samples. Nonwage income is relatively higher for the rural sample, mostly from the inflow of remittances. More families in rural areas in Tajikistan send migrants abroad, hence they benefit by receiving additional income in kind: on average, rural families receive monthly non-wage income of 556 Somoni, while urban families receive 458 Somoni.

\section{Determinants of Labour Force Participation}

We estimate the effects of individual and family characteristics on individual LFP decisions using the probit model. Our dependent variable, LFP, takes a value of one if an individual worked in last 14 days including any occasional work and zero otherwise. Explanatory variables include individual characteristics such as individual ages, education level, gender, whether he or she is the head of household, migration experience, ethnicity and marriage, as well as household's characteristics such as living in urban areas and different country's regions, size of household, number of children in the household with ages of less than 6, and ages from 6 to 17 , number of elders with ages of older than 65, having a current migrant relative abroad, and the size of other monthly non-wage income. We estimate probit equations for each of whole, urban and rural sample. The first equation is estimated for all people in the sample including gender. The second and third equations are estimated for men and women, respectively. Table 5 reports probit estimates, as well as the marginal effects of each variable on the probability of LFP, for 
the whole sample. Tables 6 and 7 provide probit estimates and marginal effects for the rural and urban samples, respectively.

We look at the effect of two factors of our interest, migration and education. Returned migrants $($ Mig_Exp $=1)$ are less likely to be working. The marginal effect of the variable defining whether an individual was a migrant in last 12 months on the probability of working is negative and significant. The relationship is strong mainly for men and is not significant for women; migration in Tajikistan is male dominated, and there are few female migrants in our sample. The discouragement effect of migration experience in the domestic labour market is stronger for urban return migrants in comparison to rural returnees: migration experience significantly reduces the probability of working by urban and rural men of $27.1 \%$ and $18.2 \%$, respectively.

Having a migrant relative who currently works abroad (Mig_HH $=1$ ) reduces the respondent's probability of working. The coefficient on the dummy variable defining whether the household has a current migrant is negative and significant. Having a current migrant in the family reduces the individual probability of working by $4.7 \%$. Since the income effect of remittances is captured by other nonwage income, i.e. keeping the effect of remittances constant, the dummy variable on current migrant reflects the demonstration effect of migration: migrants' male relatives do not work since they may also plan to migrate observing the benefits of migration by relatives. Indeed, since Tajikistan's migration is male dominated, having a migrant relative is not significantly related to the likelihood of working for women, but is significantly 
negative on men's probability of working. ${ }^{3}$ Furthermore, it is mainly rural men whose LFP decision is impacted by relative's migration; we do not observe any significant effect of having a current migrant relative on the likelihood of working for the urban sample. As most migrants are from the rural areas of Tajikistan, it seems natural to observe a strong demonstration effect of migration for the rural male sample.

The variables defining the levels of education show an increasing relationship between education and the probability of working. The reference education level is primary education. At the sample average, having education from secondary general schools is not significantly different than primary education. The estimate on the dummy capturing secondary general education is positive but not significant for the whole sample. After the sample is divided into urban and rural, the effect of having a secondary general education becomes important for urban men: its estimate is positive and significant. In other words, men with such education are more likely to work than those with the lowest (i.e. primary) education in urban areas. Professional education has a significantly positive effect on the probability of working. Receiving education from special and technical schools (vocational education) increases the probability of working by $12 \%$ for the whole sample - its estimate is positive and significant. Having a higher professional education further increases the probability of working: a university education increases the chances of being employment by $22.2 \%$ for the whole sample. The effect of professional education is strong for women, the marginal effects of professional education on the probability of working doubles for women, but is smaller for men. This finding is persistent in the probit

\footnotetext{
${ }^{3}$ For women, having migrant relatives after controlling remittance is likely to increase labor market participation because a working member is absent and demonstration effect will be negligible considering low probability of female migration.
} 
models estimated using the urban and rural samples. In other words, having professional education is very important for female LFP. The effect of professional education is stronger for men living in urban areas than in rural areas: having a special and technical education increases the probability of working for men living in urban areas by $13.5 \%$ and rural areas by $2.6 \%$; and having a university degree increases such probability by $17.2 \%$ and $7.6 \%$ in urban and rural areas, respectively.

For the whole sample, age dummy variables show an inverse-U relationship between the probability of working and individual age. The reference age is from 25 to 29 years old. Older respondents are more likely to be working, except those 50 to 55 years old whose coefficient is negative, though not significant. Being 30-34 years old has a slightly larger positive and significant effect on working than the reference age. The probability of working is highest for ages from 35-39, its marginal effect is almost at $10 \%$ for the whole sample. The marginal effect of age on the probability of working reduces to $9.4 \%$ for ages $40-44$, then to $7 \%$ for ages $45-49$. The age effect on the probability of employment is strong mainly for women: the estimates are significant for women sample estimates for age groups of 35-39, 40-44, and 45-49, but are not significant for every male age group. A similar pattern can be found when the samples are divided into rural and urban samples. As men enter the labour force earlier, we do not observe any significant difference between age categories on the probability of working. However, urban men at ages 50-55 are more likely to not work in comparison to those 25-29 years old: the estimate for the 50-55 age category in the urban sample is negative for men and significant. On the other hand, urban women's participation in the labour force after the age of 35 steadily increases until the age of 50 . 
Heads of Household are more likely to work; its estimate for whole sample is positive and also significant. The marginal effect is $10.5 \%$ for the whole sample. The marginal effect of being a head on the probability of working is larger for women than men: being a head increases the chance of employment by $12.8 \%$ for women, and $7.8 \%$ for men. Such effects are persistent for both rural and urban samples.

Marriage does not affect the probability of working; the estimate on its dummy variable is not significant for the whole sample. While for the female sample its probit estimate is negative and significant - married women are less likely to work. The marriage reduces the probability of women working by $9.2 \%$ for the whole female sample, by $9.9 \%$ for the rural female sample, and $12.8 \%$ for the urban female sample. However, being a married man increases the probability of working; the corresponding estimate for the male sample is positive and significant across all three samples. Marriage for men increases their probability of working by $18.4 \%$ for the whole male sample, $17.8 \%$ for the rural male sample, and $21.2 \%$ for the urban male sample.

Ethnic disparity in employment in Tajikistan is also found, though not consistent across samples. Overall ethnic Tajiks are less likely to work than non-Tajik ethnic groups. The estimate on the dummy variable on Tajik ethnicity is negative and significant for both whole and rural samples, but not significant for the urban sample. Tajik women are less likely to work than nonTajik women at the whole sample. This effect is strong in rural areas, while showing no significant difference between Tajik and non-Tajik women's employment in urban areas. The probability of working is reduced by $7.2 \%$ for Tajik women in rural areas. Ethnicity, however, does not have any effect on men's work decision across all three samples. 
Living in urban areas is associated with reduction in probability of working. The estimate on the dummy of living in an urban area for all people is negative and significant. The effect of this variable is stronger for women than for men: living in the urban area reduces the probability of working of women by $8.2 \%$, significant, and of men by $3.5 \%$, significant. Regional differences on LFP are significant. People in Khatlon province and Regions of Republican Subordination are more likely to work than those who live in the capital (Dushanbe) for the whole sample. Their corresponding marginal effects on the probability of working are $9.2 \%$, and $5 \%$, respectively. These regional effects are stronger for women than for men: living in Khatlon province and Regions of Republican Subordination increases the probability of working for women by $21.6 \%$ and $5.8 \%$, respectively. Both areas were torn by the civil war, and are largely dependent on agricultural production. While living in Sogd and Badakhshan for the whole sample does not have a significant effect on employment comparatively to those who live in the capital. However, when men and women are separately estimated, living in Badakhshan increases probability of working by $8.8 \%$ for women, but reduces it by $14.4 \%$ for men.

For the rural sample, the reference group is Sogd province. Compared to the rural areas of Sogd province, living in Khatlon province increases the probability of working by $23.8 \%$ for women, but reduces it by $5.9 \%$ for men. Though smaller, positive and significant effects are found for living in rural areas of Regions of Republican Subordination and Badakhshan province for women. There is no difference for men in working in rural areas of Sogd Province and Regions of Republican Subordination. While men living in rural areas of Badakhshan province are less likely to work: the marginal effect on the probability of working is negative (-15.6\%) and significant. 
In the urban sample, living in Sogd province increases the probability of women working but not men relative to living in the capital (Dushanbe). For women, living in urban areas of Sogd province increases the likelihood of working by $16.5 \%$ compared to those living in the capital. Living in urban areas of Badakhshan province increases the probability of working by $16.2 \%$ for women and reduces it by $20.7 \%$ for men compared to those living in the capital. However, living in urban areas of Khatlon province and Regions of Republican Subordination for both men and women do not have any significant impact on the likelihood of working relative to those living in the capital.

Household size does not have any significant effect on the probability of working for the whole sample. When estimated by gender, the effect is significant for men but not for women. An increase in household size reduces the probability of working for men; the estimate is negative and significant. However, when the model is estimated by rural and urban, size of household has significantly positive effect for only women in urban areas.

The number of children with ages less than 6 years old decreases the probability of working. The estimate is negative and significant. This effect is strong for women and significant, but not significant for men. Women with young children choose not to work and look after their children, once children become older, parents decide to return to work again. The effect of number of children with ages of younger than 6 years old is stronger for women in urban than rural areas. An additional child younger than 6 years old lowers the probability of working by $7.1 \%$ and $2.4 \%$ for women living in urban and rural areas, respectively.

Furthermore, the number of children in ages of 6 to 17 and the number of elders with ages 65 and older do not have any significant impact on the probability of working for the whole and rural samples. However, for the urban sample, number of elders reduces the probability of 
working by $6 \%$ for women, but does not have any significant impact on men. The number of children in ages of 6 to 17 also does not have any impact on working for both men and women in urban areas.

Other non-wage income has a positive and significant, though small, impact on the employment probability for the whole sample. However, when we look at subgroups, the positive effect is found only for men living rural areas. Since poverty is high in Tajikistan, most families are likely to keep working despite the additional income they receive from other sources including remittances.

In the probit equations when a pooled sample of men and women is used, gender disparity is captured by the female categorical variable. Its coefficient estimate is negative and statistically significant. Keeping the effect of other individual and household characteristics constant, women are less likely to work by $36.1 \%$ for the whole sample, $36 \%$ for the rural sample, and $38.2 \%$ for the urban sample. This specification is restrictive in the sense that it constrains men and women to have the same coefficients for all explanatory variables except for the intercept. In the next section, we study the gender gap in LFP rates utilizing the probit estimates for separate samples which do not have any restriction on the estimates of the models.

It is quite plausible that labour force participation (LFP) and migration decision (Mig_Exp) are correlated, i.e., Mig_Exp is an endogenous variable in the LFP equation. This issue is widely recognized, but is not easy to overcome due to various conceptual and data issues. Nonetheless we have estimated a bivariate probit model for men and women to account for the potential endogeneity of the migration variable in the LFP decision. The results for the men and 
women in the whole sample are reported in the Table Appendix. ${ }^{4}$ Focusing on the results for men, the bivariate probit estimates of LFP equation are not qualitatively much different from those of single probit estimates reported in Table 5. This may be quite natural considering that the correlation coefficient $(\rho)$ is close to zero. We also find this in bivariate estimations for men in rural and urban samples. Though these results do not completely resolve the endogeneity issues, we use single probit estimates in decomposition analysis since bivariate probit estimation is hard to obtain for the women's sample due to the small sample size of female migrants, and it is desirable to have the same econometric models for men and women in decomposition analysis.

\section{Decomposing the Gender Gap in Labour Force Participation}

Using Oaxaca type decomposition of differences in binary variables, we explain the gender gap in LFP in Tajikistan. Oaxaca (1973) and Blinder (1973) introduced regression based decomposition for studying differences between groups. We use the decomposition method proposed by Yun (2004; 2005b; 2008) for discrete dependant variables. The likelihood of participating in the labour force for individual $i$ is estimated by $\Phi\left(X_{i} \beta\right)$, where $X_{i}$ is a $1 \times$ $k$ vector of explanatory variables, $\beta$ is a $k \times 1$ vector of coefficients, and $\Phi$ is a standard normal cumulative distribution function. The observed LFP rate is asymptotically equal to sample average of the individual likelihood of LFP:

$$
\overline{L F P}=\overline{\Phi(X \beta)}=\frac{1}{\mathrm{~N}} \sum_{i=1}^{N} \Phi\left(X_{i} \beta\right) .
$$

\footnotetext{
${ }^{4} \mathrm{~A}$ major problem with our bivariate probit is the very small sample of women who migrated, which causes difficulty in estimating the bivariate probit model when rural and urban samples are separately studied.
} 
Algebraically, the difference in the average likelihoods of LFP between male (A) and female $(B)$ may be decomposed as:

$$
\overline{L F P}_{A}-\overline{L F P}_{B}=\left[\overline{\Phi\left(X_{A} \beta_{A}\right)}-\overline{\Phi\left(X_{B} \beta_{A}\right)}\right]+\left[\overline{\Phi\left(X_{B} \beta_{A}\right)}-\overline{\Phi\left(X_{B} \beta_{B}\right)}\right],
$$

where the first and the second components on the right-hand side represent the "characteristics effect" and "coefficients effect", respectively; and an "over bar" represents the value of the sample’s average.

This decomposition provides us with the overall characteristics and coefficients effects. In order to find the relative contribution of each variable to the gender gap in LFP, in terms of characteristics and coefficients effects, we employ a decomposition equation for the probit model as proposed by Yun (2004):

$$
\overline{L F P}_{A}-\overline{L F P}_{B}=\sum_{j=1}^{k} W_{\Delta X}^{j}\left[\overline{\Phi\left(X_{A} \beta_{A}\right)}-\overline{\Phi\left(X_{B} \beta_{A}\right)}\right]+\sum_{j=1}^{k} W_{\Delta \beta}^{j}\left[\overline{\Phi\left(X_{B} \beta_{A}\right)}-\overline{\Phi\left(X_{B} \beta_{B}\right)}\right],
$$

where $W_{\Delta X}^{j}=\frac{\left(\bar{X}_{A}^{j}-\bar{X}_{B}^{j}\right) \beta_{A}^{j}}{\left(\bar{X}_{A}-\bar{X}_{B}\right) \beta_{A}}, W_{\Delta \beta}^{j}=\frac{\bar{X}_{B}^{j}\left(\beta_{A}^{j}-\beta_{B}^{j}\right)}{\bar{X}_{B}\left(\beta_{A}-\beta_{B}\right)}$, and $\sum_{j=1}^{k} W_{\Delta \beta}^{j}=\sum_{j=1}^{k} W_{\Delta X}^{j}=1$, while $\bar{X}_{A}^{j}$ and $\bar{X}_{B}^{j}$ are average values of explanatory variable $j$ for groups $A$ and $B$, respectively. ${ }^{5}$

${ }^{5}$ For computing asymptotic standard errors of the characteristics and coefficients effects, see Yun (2005a). Robustness issues, known as the index or parameterization problem and the identification problem, have been dealt with in the detailed decompositions. A decomposition equation with a different parameterization $\left[\left(\Phi\left(X \_A \beta \_A\right)\right)^{-}-\left(\Phi\left(X \_B \beta \_A\right)\right)^{-}\right]+\left[\left(\Phi\left(X \_B \beta \_A\right)\right)^{-}-\left(\Phi\left(X \_B \beta \_B\right)\right)^{-}\right]$was computed; the results are not substantially different. Another interpretation issue is that the coefficients effect in the detailed decomposition is not invariant to the choice of omitted groups when dummy variables are used (Oaxaca and Ransom, 1999). The solution suggested by Yun (2005b; 2008) is used here: as alternative reference groups yield different estimates of the coefficients effects for each individual variable, it is natural to obtain estimates of the coefficients effects for every possible omission and take the average of the coefficients effects estimates as the "true” contributions of individual variables to differentials. This can be accomplished 
The decomposition results based on normalized equations suggested in Yun (2005b, 2008) are reported in Table 8, 9 and 10 for all three samples: the whole, rural and urban samples. Our main focus is on the estimated percentage share which defines the major contributions to the gender gap in LFP. The method decomposes the predicted differences in the LFP rates of women and men into characteristics and coefficients effects. ${ }^{6}$ For the whole sample, the overall (aggregate) characteristics effect accounts for $9.1 \%$ of the total gender gap of $39.7 \%$, whereas the overall coefficients effect accounts for $90.9 \%$ of the total gender gap. Both characteristics and coefficients effects are significant. These results suggest that the gender gap in LFP is less dependent on the differences in male and female characteristics, but is largely driven by behavioural differences (probit coefficients) between men and women. Though equalizing attributes between men and women will help reduce the gender gap in LFP, it is not likely to be reduced substantially unless women act more like men (or men act like women) in Tajikistan. Both rural and urban samples also show that most of the gender gap in LFP is explained by the coefficients effect: the characteristics and coefficients effects are $14.4 \%$ and $85.7 \%$, respectively, for urban sample, and 6.5\% and 93.5\%, respectively, for rural sample. All characteristics and coefficients effects are significant except for the characteristics effect for rural sample, which is significant.

with a single estimation by transforming the probit estimates into a normalized equation and using the normalized equation for the decomposition.

${ }^{6}$ The predicted gender gap of LFP is $39.7 \%(=77.2 \%-37.5 \%)$ for the whole sample, $38.7 \%$ (=77.4\% - 38.7\%) for rural sample, and $42.7 \%$ (=76.5\% - 33.8\%) for urban sample, respectively. The observed gender gaps of LFP are $39.7 \%$, 38.7\%, and $42.6 \%$ for the whole sample, rural sample, and urban sample, respectively. 
For the detailed decomposition, we focus on the contribution of migration and education to the gender gap in LFP. First, look at the migration variables. The probit estimates of migration variables (Mig_Exp and Mig_HH) indicate that they tend to decrease the likelihood of participation. There is a huge gap in own migration experience between men and women since Tajikistan's migration is male dominated. This leads to a negative characteristics effect for having migration experience (Mig_Exp), meaning that the LFP gender gap would be widened if the gender gap in migration experience disappears, i.e., if male dominance in migration disappears. On the other hand, the characteristics effect of having migrant relatives (Mig_HH) is positive because women have larger responses to having relatives who have migrated. If this disparity disappears, then the LFP gender gap narrows. The coefficients effects of both Mig_Exp and $\mathrm{Mig}_{-} \mathrm{HH}$ are negative (e.g., -0.0008 and -0.0031 , respectively, for the whole sample), however, only the coefficients effect of own migration experience (Mig_Exp) is significant; these results indicate that the participation discouraging effects of these variables are stronger for men. This seems natural considering that most of migrants are male in Tajikistan. Hence, if the discouragement effect of migration is equalized between men and women, the gender gap of LFP is widened.

Next we look at the detailed decomposition for the education variables. Overall, both characteristics and coefficients effects of education variables are positive. This means that if the differences in educational attainments and their participation enhancing effects disappear, the gender gap in LFP shrinks. From the mean characteristics given in Table 4, we show that, on average, men have better educational attainment, particularly vocational and university education. Therefore, it is necessary for more women to participate in vocational and university education in order to reduce the gender gap in LFP. This finding is reinforced as the participation 
increasing effects of vocational and university education are much stronger for women. This leads to negative coefficients effects of these education levels (EducVoc and EducHigh), while the coefficients effects of other education variables (EducPrimary and EducGen) are positive.

\section{Conclusion}

Tajikistan - a small and landlocked country - underwent a serious economic and political transformation after independence from the Soviet Union in 1991. Over the last two decades it evolved into the world's most migrant remittance dependent country with much of its labour force working abroad (mainly Russia). At the same time, Tajikistan has a well-developed educational system which, while not free from discrimination, leans that way. Tajikistan provides a good case for studying the roles of massive emigration and education on domestic labour supply decisions. With samples from World Bank Living Standard Measurement Survey on Tajikistan in 2007, we study the correlates of LFP and its gender gap.

Using probit and decomposition analysis, we find that education and migration have a significant and important relationship with the gender gap in LFP in Tajikistan. That is, international migration, mainly by men, reduces participation by men domestically, while women's education increases female participation; both women's greater access to education, particularly to higher education, and increased international migration contribute to reducing the gender gap.

Access to higher education increases employment opportunities for women. Since professional education schools are mainly concentrated in urban areas, the primary policy implication of our result might be to expand the accessibility of such education to women either by providing scholarships for young women to accomplish studies at universities, or encourage 
opening new universities or branches in rural areas. We also find that Tajikistan's men are more responsive to migration and are more likely than women to leave the labour force. Where there is significant emigration, male migration might shrink the gender gap in LFP but at the cost of reducing of the male labour supply and the overall employment. 


\section{References}

Abdulloev, I. (2013) Impact of Migration on Job Satisfaction, Professional Education and the Informal Sector. PhD Dissertation, Rutgers University, New Brunswick, NJ.

Acosta, P. (2006) Labor Supply, School Attendance, and Remittances from International Migration: the Case of El Salvador. The World Bank Policy Research Working Paper Series 3903, doi:10.1596/1813-9450-3903.

Amuedo-Dorantes, C. and Pozo, S. (2006) Migration, Remittances, and Male and Female Employment Patterns. American Economic Review 96(2): 222-226.

Becker, G. (1991) A Treatise on the Family. Enlarged ed. Cambridge, MA: Harvard University Press.

Blinder, A. (1973) Wage Discrimination: Reduced Form and Structural Estimates. Journal of Human Resources 8(4): 436-455.

Blunch, N.-H. (2010) The Gender Earnings Gap Revisited: A Comparative Study for Serbia and Five Countries in Eastern Europe and Central Asia. Retrieved from: http://siteresources.worldbank.org/INTECA/Resources/GenderEarningsGap.pdf

Cabegin, E. C. (2006) The Effect of Filipino Overseas Migration on the Non-Migrant Spouse's Market Participation and Labor Supply Behavior. IZA Discussion Paper No. 2240. Retrieved from: http://ftp.iza.org/dp2240.pdf.

Cunningham, W. (2001) Breadwinner or Caregiver? How Household Role Affects Labor Choices in Mexico. In: E. Katz and M. Correia (eds.) The Economics of Gender in Mexico: Work, Family, State, and Market. Washington, D.C.: World Bank, pp. 85-132.

Goldin, C. (1995) The U-Shaped Female Labor Force Function in Economic Development and Economic History. In: T.P. Schultz (ed.) Investment in Women's Human Capital and Economic Development. Chicago, IL: University of Chicago Press, pp. 61-90.

Hadi, A. (2001) International Migration and the Change of Women's Position among the LeftBehind in Rural Bangladesh. International Journal of Population Geography 7: 53-61.

Hondagneu-Sotelo, P. (1992) Overcoming Patriarchal Constraints: The Reconstruction of Gender Relations among Mexican Immigrant Women and Men. Gender and Society 6(3): 393415.

Killingsworth, M. and Heckman, J. (1987) Female labor supply: A survey. In: in O. Ashenfelter and R. Layard (eds) Handbook of Labor Economics. Elsevier, edition 1, volume 1, number 1, pp. 103-204. 
Klasen, S. and Pieters, J. (2012) Push or Pull? Drivers of Female Labor Force Participation during India's Economic Boom. IZA Discussion Paper No. 6395. Retrieved from: http://ftp.iza.org/dp6395.pdf.

Mammen, K. and Paxson, C. (2000) Women's Work and Economic Development. Journal of Economic Perspectives 14(4): 141-164.

Mincer, J. (1974) Schooling, Experience, and Earnings. National Bureau of Economic Research Books, Inc. Retrieved from: http://EconPapers.repec.org/RePEc:nbr:nberbk:minc74-1.

Neumark, D. and McLennan, M. (1995) Sex Discrimination and Women's Labor Market Outcomes. The Journal of Human Resources 30(4), 713-740.

Nguyen, T. and Purnamasari, R. (2011) Impacts of International Migration and Remittances on Child Outcomes and Labor Supply in Indonesia: How Does Gender Matter? The World Bank Policy Research Working Paper Series, No 5591, doi:10.1596/1813-9450-5591.

Oaxaca, R. (1973) Male-Female Wage Differentials in Urban Labor Markets. International Economic Review 14(3): 693-709.

Oaxaca, R. and Ransom, M. (1999) Identification in Detailed Wage Decompositions. The Review of Economics and Statistics 81(1): 154-157.

Paris, T., Singh, A., Luis, J. and Hossain, M. (2005) Labour Outmigration, Livelihood of Rice Farming Households and Women Left Behind: A Case Study in Eastern Uttar Pradesh. Economic and Political Weekly 40(25): 2522-2529.

Rodriguez, E. and Tiongson, E. (2001) Temporary Migration Overseas and Household Labor Supply: Evidence from Urban Philippines. International Migration Review 35(3): 709-725.

Safarova, M., Abdurakhmanova, A. and Kasymova, R. (2007) A Gender Analysis of EU Development Instruments and Policies in Tajikistan Representing Central Asia. EU Gender Watch: Dushanbe, Khujand. Retrieved from: http://www.neww.org.pl/download/EU_GenderWatch_Tajikistan.pdf

Semyonov, M. (1980) The Social Context of Women's Labor Force Participation: A Comparative Analysis. American Journal of Sociology 86(3): 534-550.

Shahriari, H., Danzer, A. M., Giovarelli, R., \& Undeland, A. (2009) Improving Women’s Access to Land and Financial Resources in Tajikistan. World Bank Group Gender Action Plan Report. Washington, DC: World Bank.

Signorelli, M., Choudhry, M. and Marelli, E. (2012) The Impact of Financial Crises on Female Labour. European Journal of Development Research 24: 413-433. 
Statistical Agency of Tajikistan (2010) Женщины и Мужчины Республики Таджикистан [Women and Men of the Republic of Tajikistan]. Dushanbe: Statistical Agency of Tajikistan.

Statistical Agency of Tajikistan (2011) Database. Available at: http://stat.tj/ru/database/realsector/ [Accessed 17 September 2011].

Statistical Committee of CIS (2011) Average Monthly Nominal Wage in the CIS Countries, in national currency. Available at: http://www.cisstat.com/index.html [Accessed 17 September 2011].

World Bank (2011) Migration and Remittances. Factbook 2011. Second edition. Available at: http://siteresources.worldbank.org/INTLAC/Resources/Factbook2011-Ebook.pdf [Accessed 12 August 2011].

World Bank (2013) World Data Bank. Available at: http://databank.worldbank.org/data/home.aspx [Accessed 17 May 2013].

Yun, M.-S. (2004) Decomposition Differences in the First Moment. Economics Letters 82(2): 273-278.

Yun, M.-S. (2005a) Hypothesis Tests When Decomposing Differences in the First Moment. Journal of Economic and Social Measurement 30(4): 295-304.

Yun, M.-S. (2005b) A Simple Solution to the Identification Problem in Detailed Wage Decomposition. Economic Inquiry 43(4): 766-772.

Yun, M.-S. (2008) Identification Problem and Detailed Oaxaca Decomposition: A General Solution and Inference. Journal of Economic and Social Measurement 33(1): 27-38. 
Table 1. Occupation Distribution by Gender, Working Sample, 2007 TLSS

\begin{tabular}{lrr}
\hline Occupation groups & \multicolumn{1}{c}{ Men } & Women \\
\hline Legislators, senior officials and managers & $4.6 \%$ & $1.6 \%$ \\
Professionals & $10.4 \%$ & $11.8 \%$ \\
Technicians and associate professionals & $6.2 \%$ & $11.2 \%$ \\
Clerks & $1.0 \%$ & $1.0 \%$ \\
Service workers & $12.4 \%$ & $11.0 \%$ \\
Skilled agricultural and fishery workers & $23.5 \%$ & $47.2 \%$ \\
Craft and related workers & $18.7 \%$ & $4.8 \%$ \\
Plant and machine operators and assemblers & $11.6 \%$ & $0.5 \%$ \\
Elementary occupations & $11.7 \%$ & $10.8 \%$ \\
\hline No. of observations & 3,567 & 2,109 \\
\hline
\end{tabular}

Table 2. Distribution of Employed People and Salaries by Industry and Gender in 2008

\begin{tabular}{lrrrrr}
\hline & $\begin{array}{c}\text { Employees } \\
\text { (thousands) }\end{array}$ & $\begin{array}{c}\text { Men } \\
\text { \% of } \\
\text { employed }\end{array}$ & Salaries & \multicolumn{2}{c}{ Women } \\
employed & Salaries \\
\hline All sectors & 1028.5 & $58.2 \%$ & 393.81 & $41.8 \%$ & 235.36 \\
Material Production Sectors: & 700.3 & $59.8 \%$ & 358.34 & $40.2 \%$ & 211.45 \\
$\quad$ Industry & 89.5 & $69.7 \%$ & 465.76 & $30.3 \%$ & 289.04 \\
Farming, forestry and fishing & 517.8 & $54.8 \%$ & 130.26 & $45.2 \%$ & 102.94 \\
Construction & 32 & $88.4 \%$ & 786.87 & $11.6 \%$ & 672.78 \\
Trade & 21 & $66.2 \%$ & 274.39 & $33.8 \%$ & 275.8 \\
Transport and communication & 30.3 & $74.6 \%$ & 879.47 & $25.4 \%$ & 791.94 \\
Others & 9.7 & $83.5 \%$ & 281.59 & $16.5 \%$ & 277.17 \\
Non-Material Production Sectors: & 328.2 & $54.7 \%$ & 444.78 & $45.3 \%$ & 251.43 \\
Housing utilities and consumer services & 24.9 & $63.5 \%$ & 321.42 & $36.5 \%$ & 334.02 \\
Health & 73.6 & $43.2 \%$ & 243.14 & $56.8 \%$ & 182 \\
Education & 165.1 & $55.2 \%$ & 290.37 & $44.8 \%$ & 205.44 \\
Culture, art and science & 16.5 & $50.3 \%$ & 282.14 & $49.7 \%$ & 197.24 \\
Public management and crediting & 48.1 & $67.6 \%$ & 1056.99 & $32.4 \%$ & 714.61 \\
\hline
\end{tabular}

Note: Employment data is on annual average number of employees excluding international migrants. Monthly average salaries are for December 2008, in Somoni (US\$1= 3.4519 Somoni).

Source: Statistical Agency of Tajikistan (2010) Женщины и Мужчины Республики Таджикистан [Women and Men of the Republic of Tajikistan], Dushanbe. 


\section{Table 3. Definitions of Variables used in Regressions}

\begin{tabular}{|c|c|}
\hline LFP & Dummy variable taking a value of 1 if worked in last 14 days including occasional work \\
\hline Male & Dummy variable taking a value of 1 if an individual is male \\
\hline Female & Dummy variable taking a value of 1 if an individual is female \\
\hline Age25_29 & Dummy variable taking a value of 1 if an individual's age is between $25-29$ \\
\hline Age30_34 & Dummy variable taking a value of 1 if an individual's age is between $30-34$ \\
\hline Age35_39 & Dummy variable taking a value of 1 if an individual's age is between 35-39 \\
\hline Age40_44 & Dummy variable taking a value of 1 if an individual's age is between $40-44$ \\
\hline Age45_49 & Dummy variable taking a value of 1 if an individual's age is between $45-49$ \\
\hline Age50_55 & Dummy variable taking a value of 1 if an individual's age is between $50-55$ \\
\hline Mig_Exp & Dummy variable taking a value of 1 if an individual was a migrant in last 12 months \\
\hline EducPrimary & $\begin{array}{l}\text { Dummy variable taking a value of } 1 \text { if an individual has the highest degree from a primary } \\
\text { school }\end{array}$ \\
\hline EducGen & $\begin{array}{l}\text { Dummy variable taking a value of } 1 \text { if an individual has the highest degree from the general } \\
\text { secondary school }\end{array}$ \\
\hline EducVoc & $\begin{array}{l}\text { Dummy variable taking a value of } 1 \text { if an individual has the highest degree from technical } \\
\text { or special school }\end{array}$ \\
\hline EducHigh & Dummy variable taking a value of 1 if an individual has the highest degree from university \\
\hline Head & Dummy variable taking a value of 1 if an individual is the head of the household \\
\hline Married & Dummy variable taking a value of 1 if an individual is married \\
\hline Tajik & Dummy variable taking a value of 1 if an individual has a Tajik ethnicity \\
\hline Rural & Dummy variable taking a value of 1 if an individual lives in a rural area \\
\hline Urban & Dummy variable taking a value of 1 if an individual lives an urban area \\
\hline RegionD1 & Regional dummy taking value of 1 if individual lives in the capital (Dushanbe) \\
\hline RegionD2 & Regional dummy taking value of 1 if individual lives in Sogd province \\
\hline RegionD3 & Regional dummy taking value of 1 if individual lives in Khatlon province \\
\hline RegionD4 & $\begin{array}{l}\text { Regional dummy taking value of } 1 \text { if individual lives in any of Regions of Republican } \\
\text { Subordination }\end{array}$ \\
\hline RegionD5 & Regional dummy taking value of 1 if individual lives in Badakhshan province \\
\hline HHSize & Size of the household \\
\hline Child6 & Number of children in the household with ages of less than 6 years old \\
\hline Child6_18 & $\begin{array}{l}\text { Number of children in the household with ages of greater of equal to } 6 \text { but less than } 18 \\
\text { years old }\end{array}$ \\
\hline Elder65 & Number of elders with age of 65 and older \\
\hline Mig_HH & Dummy variable taking a value of 1 if a household has a current migrant abroad \\
\hline OtherIncom 1000 & $\begin{array}{l}\text { Monthly other non-wage income in thousands of Somoni (total household income minus } \\
\text { individual work earnings). }\end{array}$ \\
\hline
\end{tabular}


Table 4. Summary Statistics: Whole, Rural and Urban Samples

\begin{tabular}{|c|c|c|c|c|c|c|c|c|c|c|c|c|c|c|c|c|c|c|}
\hline \multirow{3}{*}{ Variables } & \multicolumn{6}{|c|}{ Whole sample } & \multicolumn{6}{|c|}{ Rural sample } & \multicolumn{6}{|c|}{ Urban sample } \\
\hline & \multicolumn{2}{|c|}{ All } & \multicolumn{2}{|c|}{ Men } & \multicolumn{2}{|c|}{ Women } & \multicolumn{2}{|c|}{ All } & \multicolumn{2}{|c|}{ Men } & \multicolumn{2}{|c|}{ Women } & \multicolumn{2}{|c|}{ All } & \multicolumn{2}{|c|}{ Men } & \multicolumn{2}{|c|}{ Women } \\
\hline & Mean & SD & Mean & SD & Mean & SD & Mean & SD & Mean & SD & Mean & SD & Mean & SD & Mean & SD & Mean & SD \\
\hline LFP & 0.564 & 0.496 & 0.772 & 0.420 & 0.375 & 0.484 & 0.573 & 0.495 & 0.774 & 0.418 & 0.387 & 0.487 & 0.536 & 0.499 & 0.765 & 0.424 & 0.339 & 0.473 \\
\hline Age25_29 & 0.257 & 0.437 & 0.256 & 0.436 & 0.258 & 0.438 & 0.265 & 0.442 & 0.265 & 0.442 & 0.265 & 0.441 & 0.230 & 0.421 & 0.223 & 0.416 & 0.236 & 0.424 \\
\hline Age30_34 & 0.191 & 0.393 & 0.200 & 0.400 & 0.183 & 0.386 & 0.189 & 0.392 & 0.199 & 0.399 & 0.180 & 0.384 & 0.197 & 0.398 & 0.204 & 0.403 & 0.190 & 0.393 \\
\hline Age35_39 & 0.150 & 0.357 & 0.147 & 0.354 & 0.152 & 0.359 & 0.144 & 0.351 & 0.146 & 0.353 & 0.142 & 0.349 & 0.169 & 0.374 & 0.152 & 0.359 & 0.183 & 0.386 \\
\hline Age40_44 & 0.138 & 0.345 & 0.139 & 0.346 & 0.137 & 0.344 & 0.138 & 0.344 & 0.135 & 0.341 & 0.140 & 0.347 & 0.140 & 0.347 & 0.155 & 0.362 & 0.127 & 0.333 \\
\hline Age45_49 & 0.130 & 0.336 & 0.130 & 0.337 & 0.130 & 0.336 & 0.130 & 0.337 & 0.132 & 0.338 & 0.129 & 0.335 & 0.129 & 0.335 & 0.127 & 0.333 & 0.131 & 0.338 \\
\hline Age50_55 & 0.134 & 0.341 & 0.127 & 0.333 & 0.141 & 0.348 & 0.134 & 0.340 & 0.124 & 0.329 & 0.143 & 0.350 & 0.136 & 0.343 & 0.139 & 0.346 & 0.133 & 0.340 \\
\hline Mig_Exp & 0.055 & 0.229 & 0.109 & 0.311 & 0.007 & 0.084 & 0.058 & 0.235 & 0.114 & 0.318 & 0.007 & 0.082 & 0.046 & 0.209 & 0.090 & 0.286 & 0.008 & 0.088 \\
\hline EducPrimary & 0.184 & 0.388 & 0.115 & 0.319 & 0.247 & 0.431 & 0.195 & 0.396 & 0.122 & 0.327 & 0.263 & 0.440 & 0.149 & 0.356 & 0.091 & 0.288 & 0.199 & 0.399 \\
\hline EducGen & 0.565 & 0.496 & 0.509 & 0.500 & 0.616 & 0.486 & 0.594 & 0.491 & 0.538 & 0.499 & 0.646 & 0.478 & 0.472 & 0.499 & 0.415 & 0.493 & 0.521 & 0.500 \\
\hline EducVoc & 0.142 & 0.349 & 0.208 & 0.406 & 0.082 & 0.275 & 0.128 & 0.334 & 0.203 & 0.402 & 0.059 & 0.236 & 0.186 & 0.389 & 0.224 & 0.417 & 0.153 & 0.360 \\
\hline EducHigh & 0.109 & 0.311 & 0.168 & 0.374 & 0.055 & 0.228 & 0.082 & 0.275 & 0.137 & 0.344 & 0.032 & 0.175 & 0.193 & 0.395 & 0.270 & 0.444 & 0.127 & 0.333 \\
\hline Head & 0.253 & 0.435 & 0.467 & 0.499 & 0.058 & 0.235 & 0.235 & 0.424 & 0.445 & 0.497 & 0.042 & 0.200 & 0.309 & 0.462 & 0.539 & 0.498 & 0.111 & 0.314 \\
\hline Married & 0.879 & 0.326 & 0.923 & 0.267 & 0.839 & 0.368 & 0.885 & 0.319 & 0.923 & 0.266 & 0.850 & 0.358 & 0.859 & 0.348 & 0.922 & 0.269 & 0.805 & 0.396 \\
\hline Tajik & 0.753 & 0.431 & 0.749 & 0.433 & 0.756 & 0.429 & 0.726 & 0.446 & 0.721 & 0.449 & 0.730 & 0.444 & 0.840 & 0.367 & 0.842 & 0.364 & 0.837 & 0.369 \\
\hline Rural & 0.761 & 0.426 & 0.767 & 0.423 & 0.755 & 0.430 & & & & & & & & & & & & \\
\hline Urban & 0.239 & 0.426 & 0.233 & 0.423 & 0.245 & 0.430 & & & & & & & & & & & & \\
\hline RegionD1 & 0.078 & 0.268 & 0.073 & 0.259 & 0.083 & 0.276 & - & - & - & - & - & - & 0.327 & 0.469 & 0.312 & 0.463 & 0.339 & 0.473 \\
\hline RegionD2 & 0.294 & 0.456 & 0.297 & 0.457 & 0.291 & 0.454 & 0.293 & 0.455 & 0.294 & 0.456 & 0.292 & 0.455 & 0.298 & 0.457 & 0.309 & 0.462 & 0.288 & 0.453 \\
\hline RegionD3 & 0.367 & 0.482 & 0.374 & 0.484 & 0.360 & 0.480 & 0.404 & 0.491 & 0.409 & 0.492 & 0.399 & 0.490 & 0.250 & 0.433 & 0.259 & 0.438 & 0.242 & 0.429 \\
\hline RegionD4 & 0.233 & 0.423 & 0.229 & 0.420 & 0.236 & 0.425 & 0.272 & 0.445 & 0.268 & 0.443 & 0.275 & 0.447 & 0.110 & 0.312 & 0.103 & 0.304 & 0.115 & 0.319 \\
\hline RegionD5 & 0.028 & 0.166 & 0.027 & 0.161 & 0.030 & 0.170 & 0.032 & 0.176 & 0.030 & 0.169 & 0.034 & 0.182 & 0.016 & 0.125 & 0.017 & 0.128 & 0.015 & 0.123 \\
\hline HHSize & 8.647 & 3.400 & 8.780 & 3.407 & 8.527 & 3.390 & 8.972 & 3.333 & 9.083 & 3.337 & 8.870 & 3.326 & 7.613 & 3.406 & 7.782 & 3.445 & 7.466 & 3.365 \\
\hline Child6 & 1.396 & 1.366 & 1.445 & 1.388 & 1.352 & 1.345 & 1.446 & 1.383 & 1.489 & 1.401 & 1.407 & 1.366 & 1.235 & 1.297 & 1.300 & 1.334 & 1.179 & 1.262 \\
\hline Child6_18 & 2.287 & 1.536 & 2.245 & 1.532 & 2.324 & 1.539 & 2.384 & 1.544 & 2.338 & 1.535 & 2.426 & 1.550 & 1.977 & 1.469 & 1.938 & 1.479 & 2.011 & 1.460 \\
\hline Elder65 & 0.357 & 0.618 & 0.368 & 0.628 & 0.346 & 0.608 & 0.391 & 0.644 & 0.405 & 0.655 & 0.378 & 0.633 & 0.249 & 0.511 & 0.249 & 0.509 & 0.248 & 0.513 \\
\hline Mig_HH & 0.129 & 0.336 & 0.105 & 0.306 & 0.152 & 0.359 & 0.144 & 0.351 & 0.115 & 0.319 & 0.170 & 0.376 & 0.083 & 0.276 & 0.069 & 0.254 & 0.094 & 0.293 \\
\hline OtherIncom1000 & 0.533 & 0.811 & 0.463 & 0.791 & 0.597 & 0.824 & 0.556 & 0.858 & 0.492 & 0.849 & 0.616 & 0.862 & 0.458 & 0.633 & 0.365 & 0.546 & 0.539 & 0.689 \\
\hline No. of Samples & 10 , & & & & & & & & & & & & & & & & 1,759 & \\
\hline
\end{tabular}


Table 5. Probit Estimates and Marginal Effects: Whole Sample and by Gender (Dependent variable: worked in last 14 days, LFP)

\begin{tabular}{|c|c|c|c|c|c|c|c|c|c|}
\hline \multirow{3}{*}{$\begin{array}{l}\text { Variables } \\
\text { Age30_34 }\end{array}$} & \multicolumn{6}{|c|}{ Probit Estimates } & \multicolumn{3}{|c|}{ Marginal Effects } \\
\hline & \multicolumn{2}{|c|}{ All } & \multicolumn{2}{|c|}{ Men } & \multicolumn{2}{|c|}{ Women } & \multirow{2}{*}{$\begin{array}{c}\text { All } \\
0.0573 \\
(0.0199)\end{array}$} & \multirow{2}{*}{\begin{tabular}{r}
\multicolumn{1}{c}{ Men } \\
0.0323 \\
$(0.0229)$
\end{tabular}} & \multirow{2}{*}{$\begin{array}{r}\text { Women } \\
0.0331 \\
(0.0275)\end{array}$} \\
\hline & $\begin{array}{r}0.1484 \\
(0.0523)\end{array}$ & $* * *$ & $\begin{array}{r}0.1140 \\
(0.0832)\end{array}$ & & $\begin{array}{r}0.0873 \\
(0.0719)\end{array}$ & & & & \\
\hline Age35_39 & $\begin{array}{r}0.2590 \\
(0.0615)\end{array}$ & $* * *$ & $\begin{array}{r}0.0669 \\
(0.0983)\end{array}$ & & $\begin{array}{r}0.3447 \\
(0.0793)\end{array}$ & $* * *$ & $\begin{array}{r}0.0987 \\
(0.0227)\end{array}$ & $\begin{array}{r}0.0191 \\
(0.0276)\end{array}$ & $\begin{array}{r}0.1335 \\
(0.0312)\end{array}$ \\
\hline Age40_44 & $\begin{array}{r}0.2478 \\
(0.0622)\end{array}$ & $* * *$ & $\begin{array}{r}0.0339 \\
(0.1081)\end{array}$ & & $\begin{array}{r}0.3245 \\
(0.0782)\end{array}$ & $* * *$ & $\begin{array}{r}0.0945 \\
(0.0230)\end{array}$ & $\begin{array}{r}0.0098 \\
(0.0309)\end{array}$ & $\begin{array}{r}0.1256 \\
(0.0308)\end{array}$ \\
\hline Age45_49 & $\begin{array}{r}0.1840 \\
(0.0618)\end{array}$ & $* * *$ & $\begin{array}{c}0.0677 \\
(0.1072)\end{array}$ & & $\begin{array}{r}0.2378 \\
(0.0791)\end{array}$ & $* * *$ & $\begin{array}{c}0.0707 \\
(0.0232)\end{array}$ & $\begin{array}{r}0.0193 \\
(0.0300)\end{array}$ & $\begin{array}{r}0.0916 \\
(0.0310)\end{array}$ \\
\hline Age50_55 & $\begin{array}{l}-0.0311 \\
(0.0614)\end{array}$ & & $\begin{array}{l}-0.1671 \\
(0.1089)\end{array}$ & & $\begin{array}{r}0.0570 \\
(0.0782)\end{array}$ & & $\begin{array}{l}-0.0122 \\
(0.0241)\end{array}$ & $\begin{array}{l}-0.0510 \\
(0.0347)\end{array}$ & $\begin{array}{r}0.0216 \\
(0.0298)\end{array}$ \\
\hline Mig_Exp & $\begin{array}{l}-0.5423 \\
(0.0747)\end{array}$ & $* * *$ & $\begin{array}{l}-0.5889 \\
(0.0750)\end{array}$ & $* * *$ & $\begin{array}{r}0.0768 \\
(0.2531)\end{array}$ & & $\begin{array}{l}-0.2136 \\
(0.0284)\end{array}$ & $\begin{array}{l}-0.1986 \\
(0.0279)\end{array}$ & $\begin{array}{r}0.0292 \\
(0.0974)\end{array}$ \\
\hline EducGen & $\begin{array}{r}0.0670 \\
(0.0435)\end{array}$ & & $\begin{array}{r}0.1318 \\
(0.0819)\end{array}$ & & $\begin{array}{r}0.0076 \\
(0.0533)\end{array}$ & & $\begin{array}{r}0.0262 \\
(0.0170)\end{array}$ & $\begin{array}{r}0.0384 \\
(0.0239)\end{array}$ & $\begin{array}{r}0.0028 \\
(0.0200)\end{array}$ \\
\hline EducVoc & $\begin{array}{r}0.3190 \\
(0.0599)\end{array}$ & $* * *$ & $\begin{array}{r}0.1780 \\
(0.0907)\end{array}$ & $* *$ & $\begin{array}{r}0.5904 \\
(0.0849)\end{array}$ & $* * *$ & $\begin{array}{r}0.1206 \\
(0.0216)\end{array}$ & $\begin{array}{r}0.0497 \\
(0.0242)\end{array}$ & $\begin{array}{r}0.2311 \\
(0.0331)\end{array}$ \\
\hline EducHigh & $\begin{array}{r}0.6239 \\
(0.0690)\end{array}$ & $* * *$ & $\begin{array}{r}0.3703 \\
(0.0978)\end{array}$ & $* * *$ & $\begin{array}{r}1.0635 \\
(0.0991)\end{array}$ & $* * *$ & $\begin{array}{r}0.2224 \\
(0.0213)\end{array}$ & $\begin{array}{r}0.0970 \\
(0.0227)\end{array}$ & $\begin{array}{r}0.4021 \\
(0.0321)\end{array}$ \\
\hline Female & $\begin{array}{l}-0.9633 \\
(0.0429)\end{array}$ & $* * *$ & - & & - & & $\begin{array}{l}-0.3613 \\
(0.0148)\end{array}$ & - & \\
\hline Head & $\begin{array}{r}0.2747 \\
(0.0525)\end{array}$ & $* * *$ & $\begin{array}{r}0.2699 \\
(0.0861)\end{array}$ & $* * *$ & $\begin{array}{r}0.3294 \\
(0.0892)\end{array}$ & $* * *$ & $\begin{array}{r}0.1053 \\
(0.0196)\end{array}$ & $\begin{array}{r}0.0780 \\
(0.0246)\end{array}$ & $\begin{array}{r}0.1283 \\
(0.0355)\end{array}$ \\
\hline Married & $\begin{array}{l}-0.0307 \\
(0.0522)\end{array}$ & & $\begin{array}{r}0.5457 \\
(0.0915)\end{array}$ & $* * *$ & $\begin{array}{l}-0.2400 \\
(0.0644)\end{array}$ & $* * *$ & $\begin{array}{l}-0.0120 \\
(0.0203)\end{array}$ & $\begin{array}{r}0.1843 \\
(0.0343)\end{array}$ & $\begin{array}{l}-0.0923 \\
(0.0251)\end{array}$ \\
\hline Tajik & $\begin{array}{l}-0.1113 \\
(0.0399)\end{array}$ & $* * *$ & $\begin{array}{r}0.0171 \\
(0.0611)\end{array}$ & & $\begin{array}{l}-0.2019 \\
(0.0526)\end{array}$ & $* * *$ & $\begin{array}{l}-0.0432 \\
(0.0154)\end{array}$ & $\begin{array}{r}0.0050 \\
(0.0179)\end{array}$ & $\begin{array}{l}-0.0770 \\
(0.0203)\end{array}$ \\
\hline Urban & $\begin{array}{l}-0.1483 \\
(0.0458)\end{array}$ & $* * *$ & $\begin{array}{l}-0.1169 \\
(0.0703)\end{array}$ & $*$ & $\begin{array}{l}-0.2229 \\
(0.0634)\end{array}$ & $* * *$ & $\begin{array}{l}-0.0583 \\
(0.0181)\end{array}$ & $\begin{array}{l}-0.0349 \\
(0.0214)\end{array}$ & $\begin{array}{l}-0.0819 \\
(0.0227)\end{array}$ \\
\hline RegionD2 & $\begin{array}{r}0.0982 \\
(0.0600)\end{array}$ & & $\begin{array}{r}0.0607 \\
(0.0973)\end{array}$ & & $\begin{array}{r}0.1229 \\
(0.0832)\end{array}$ & & $\begin{array}{r}0.0382 \\
(0.0232)\end{array}$ & $\begin{array}{r}0.0175 \\
(0.0277)\end{array}$ & $\begin{array}{r}0.0466 \\
(0.0318)\end{array}$ \\
\hline RegionD3 & $\begin{array}{r}0.2388 \\
(0.0607)\end{array}$ & $* * *$ & $\begin{array}{l}-0.1267 \\
(0.0961)\end{array}$ & & $\begin{array}{r}0.5667 \\
(0.0819)\end{array}$ & $* * *$ & $\begin{array}{r}0.0925 \\
(0.0232)\end{array}$ & $\begin{array}{l}-0.0373 \\
(0.0288)\end{array}$ & $\begin{array}{r}0.2156 \\
(0.0312)\end{array}$ \\
\hline RegionD4 & $\begin{array}{r}0.1290 \\
(0.0629)\end{array}$ & $* *$ & $\begin{array}{r}0.1321 \\
(0.1039)\end{array}$ & & $\begin{array}{r}0.1521 \\
(0.0861)\end{array}$ & * & $\begin{array}{r}0.0500 \\
(0.0241)\end{array}$ & $\begin{array}{r}0.0374 \\
(0.0285)\end{array}$ & $\begin{array}{r}0.0579 \\
(0.0331)\end{array}$ \\
\hline RegionD5 & $\begin{array}{l}-0.0653 \\
(0.0698)\end{array}$ & & $\begin{array}{l}-0.4310 \\
(0.1065)\end{array}$ & $* * *$ & $\begin{array}{r}0.2279 \\
(0.0945)\end{array}$ & $* *$ & $\begin{array}{l}-0.0257 \\
(0.0276)\end{array}$ & $\begin{array}{l}-0.1438 \\
(0.0393)\end{array}$ & $\begin{array}{r}0.0882 \\
(0.0374)\end{array}$ \\
\hline HHSize & $\begin{array}{c}-0.0021 \\
(0.0100)\end{array}$ & & $\begin{array}{c}-0.0294 \\
(0.0165)\end{array}$ & * & $\begin{array}{r}0.0053 \\
(0.0132)\end{array}$ & & $\begin{array}{c}-0.0008 \\
(0.0039)\end{array}$ & $\begin{array}{c}-0.0086 \\
(0.0048)\end{array}$ & $\begin{array}{r}0.0020 \\
(0.0050)\end{array}$ \\
\hline Child6 & $\begin{array}{l}-0.0513 \\
(0.0216)\end{array}$ & $* *$ & $\begin{array}{r}0.0094 \\
(0.0350)\end{array}$ & & $\begin{array}{l}-0.0910 \\
(0.0290)\end{array}$ & $* * *$ & $\begin{array}{l}-0.0200 \\
(0.0084)\end{array}$ & $\begin{array}{r}0.0027 \\
(0.0102)\end{array}$ & $\begin{array}{l}-0.0342 \\
(0.0109)\end{array}$ \\
\hline Child6_18 & $\begin{array}{r}0.0214 \\
(0.0163)\end{array}$ & & $\begin{array}{r}0.0415 \\
(0.0263)\end{array}$ & & $\begin{array}{r}0.0296 \\
(0.0214)\end{array}$ & & $\begin{array}{r}0.0084 \\
(0.0064)\end{array}$ & $\begin{array}{r}0.0121 \\
(0.0076)\end{array}$ & $\begin{array}{r}0.0111 \\
(0.0081)\end{array}$ \\
\hline Elder65 & $\begin{array}{l}-0.0085 \\
(0.0296)\end{array}$ & & $\begin{array}{r}0.0218 \\
(0.0485)\end{array}$ & & $\begin{array}{l}-0.0187 \\
(0.0399)\end{array}$ & & $\begin{array}{l}-0.0033 \\
(0.0116)\end{array}$ & $\begin{array}{r}0.0064 \\
(0.0141)\end{array}$ & $\begin{array}{l}-0.0070 \\
(0.0150)\end{array}$ \\
\hline Mig_HH & $\begin{array}{c}-0.1190 \\
(0.0462)\end{array}$ & $* * *$ & $\begin{array}{l}-0.1945 \\
(0.0764)\end{array}$ & $* *$ & $\begin{array}{l}-0.0818 \\
(0.0597)\end{array}$ & & $\begin{array}{l}-0.0469 \\
(0.0183)\end{array}$ & $\begin{array}{l}-0.0600 \\
(0.0248)\end{array}$ & $\begin{array}{l}-0.0304 \\
(0.0220)\end{array}$ \\
\hline OtherIncome1000 & $\begin{array}{r}0.0464 \\
(0.0210)\end{array}$ & $* *$ & $\begin{array}{r}0.1396 \\
(0.0453)\end{array}$ & $* * *$ & $\begin{array}{r}0.0148 \\
(0.0282)\end{array}$ & & $\begin{array}{r}0.0181 \\
(0.0082)\end{array}$ & $\begin{array}{r}0.0407 \\
(0.0131)\end{array}$ & $\begin{array}{r}0.0056 \\
(0.0106)\end{array}$ \\
\hline Constant & $\begin{array}{r}0.4325 \\
(0.1135) \\
\end{array}$ & $* * *$ & $\begin{array}{r}0.1601 \\
(0.1722) \\
\end{array}$ & & $\begin{array}{l}-0.4826 \\
(0.1348) \\
\end{array}$ & $* * *$ & - & - & \\
\hline $\mathrm{N}$ & 10,10 & & 4,66 & & 5,44 & & & & \\
\hline Pseudo R2 & 0.160 & & 0.06 & & 0.08 & & & & \\
\hline
\end{tabular}

For all tables below, standard errors in parentheses, ${ }^{*} \mathrm{p}<.10,{ }^{* *} \mathrm{p}<.05$, *** $\mathrm{p}<.01$ 
Table 6. Probit Estimates and Marginal Effects: Rural Sample and by Gender (Dependent variable: worked in last 14 days, LFP)

\begin{tabular}{|c|c|c|c|c|c|c|c|c|c|}
\hline \multirow{3}{*}{$\begin{array}{l}\text { Variables } \\
\text { Age30_34 }\end{array}$} & \multicolumn{6}{|c|}{ Probit Estimates } & \multicolumn{3}{|c|}{ Marginal Effects } \\
\hline & \multicolumn{2}{|l|}{ All } & \multicolumn{2}{|c|}{ Men } & \multicolumn{2}{|c|}{ Women } & \multirow{2}{*}{$\begin{array}{c}\text { All } \\
0.0582 \\
(0.0231)\end{array}$} & \multirow{2}{*}{$\begin{array}{c}\text { Men } \\
0.0351 \\
(0.0260)\end{array}$} & \multirow{2}{*}{$\begin{array}{r}\text { Women } \\
0.0384 \\
(0.0320)\end{array}$} \\
\hline & $\begin{array}{r}0.1516 \\
(0.0610)\end{array}$ & $* *$ & $\begin{array}{r}0.1250 \\
(0.0956)\end{array}$ & & $\begin{array}{r}0.1000 \\
(0.0829)\end{array}$ & & & & \\
\hline Age35_39 & $\begin{array}{r}0.2588 \\
(0.0732)\end{array}$ & $* * *$ & $\begin{array}{r}0.0805 \\
(0.1139)\end{array}$ & & $\begin{array}{r}0.3878 \\
(0.0943)\end{array}$ & $* * *$ & $\begin{array}{r}0.0979 \\
(0.0268)\end{array}$ & $\begin{array}{r}0.0228 \\
(0.0315)\end{array}$ & $\begin{array}{r}0.1515 \\
(0.0373)\end{array}$ \\
\hline Age40_44 & $\begin{array}{r}0.2562 \\
(0.0732)\end{array}$ & $* * *$ & $\begin{array}{r}0.1097 \\
(0.1296)\end{array}$ & & $\begin{array}{r}0.3306 \\
(0.0918)\end{array}$ & $* * *$ & $\begin{array}{r}0.0969 \\
(0.0267)\end{array}$ & $\begin{array}{r}0.0307 \\
(0.0351)\end{array}$ & $\begin{array}{r}0.1290 \\
(0.0363)\end{array}$ \\
\hline Age45_49 & $\begin{array}{r}0.1650 \\
(0.0720)\end{array}$ & $* *$ & $\begin{array}{r}0.1417 \\
(0.1265)\end{array}$ & & $\begin{array}{r}0.1929 \\
(0.0928)\end{array}$ & $* *$ & $\begin{array}{r}0.0631 \\
(0.0270)\end{array}$ & $\begin{array}{r}0.0393 \\
(0.0335)\end{array}$ & $\begin{array}{r}0.0747 \\
(0.0364)\end{array}$ \\
\hline Age50_55 & $\begin{array}{l}-0.0022 \\
(0.0712)\end{array}$ & & $\begin{array}{l}-0.0649 \\
(0.1340)\end{array}$ & & $\begin{array}{r}0.0398 \\
(0.0892)\end{array}$ & & $\begin{array}{l}-0.0009 \\
(0.0277)\end{array}$ & $\begin{array}{l}-0.0192 \\
(0.0403)\end{array}$ & $\begin{array}{r}0.0152 \\
(0.0342)\end{array}$ \\
\hline Mig_Exp & $\begin{array}{l}-0.5218 \\
(0.0837)\end{array}$ & $* * *$ & $\begin{array}{l}-0.5458 \\
(0.0847)\end{array}$ & $* * *$ & $\begin{array}{l}-0.0412 \\
(0.2905)\end{array}$ & & $\begin{array}{l}-0.2058 \\
(0.0323)\end{array}$ & $\begin{array}{l}-0.1815 \\
(0.0310)\end{array}$ & $\begin{array}{l}-0.0156 \\
(0.1090)\end{array}$ \\
\hline EducGen & $\begin{array}{r}0.0360 \\
(0.04920\end{array}$ & & $\begin{array}{r}0.0630 \\
(0.0920)\end{array}$ & & $\begin{array}{r}-0.0006 \\
(0.0605)\end{array}$ & & $\begin{array}{r}0.0140 \\
(0.0191)\end{array}$ & $\begin{array}{r}0.0183 \\
(0.0267)\end{array}$ & $\begin{array}{l}-0.0002 \\
(0.0230)\end{array}$ \\
\hline EducVoc & $\begin{array}{c}0.2062 \\
(0.0724)\end{array}$ & $* * *$ & $\begin{array}{c}0.0907 \\
(0.1042)\end{array}$ & & $\begin{array}{c}0.4764 \\
(0.1104)\end{array}$ & $* * *$ & $\begin{array}{c}0.0785 \\
(0.0268)\end{array}$ & $\begin{array}{c}0.0257 \\
(0.0289)\end{array}$ & $\begin{array}{c}0.1874 \\
(0.0435)\end{array}$ \\
\hline EducHigh & $\begin{array}{r}0.5084 \\
(0.0923)\end{array}$ & $* * *$ & $\begin{array}{r}0.2879 \\
(0.1181)\end{array}$ & $* *$ & $\begin{array}{r}1.0686 \\
(0.1570)\end{array}$ & $* * *$ & $\begin{array}{r}0.1827 \\
(0.0295)\end{array}$ & $\begin{array}{r}0.0762 \\
(0.0282)\end{array}$ & $\begin{array}{r}0.4002 \\
(0.0485)\end{array}$ \\
\hline Female & $\begin{array}{l}-0.9639 \\
(0.0509)\end{array}$ & $* * *$ & & & & & $\begin{array}{l}-0.3600 \\
(0.0175)\end{array}$ & & \\
\hline Head & $\begin{array}{r}0.2658 \\
(0.0641)\end{array}$ & $* * *$ & $\begin{array}{r}0.2284 \\
(0.1044)\end{array}$ & $* *$ & $\begin{array}{r}0.3094 \\
(0.1202)\end{array}$ & $* * *$ & $\begin{array}{r}0.1012 \\
(0.0238)\end{array}$ & $\begin{array}{r}0.0654 \\
(0.0295)\end{array}$ & $\begin{array}{r}0.1212 \\
(0.0479)\end{array}$ \\
\hline Married & $\begin{array}{l}-0.0290 \\
(0.0632)\end{array}$ & & $\begin{array}{r}0.5319 \\
(0.1076)\end{array}$ & $* * *$ & $\begin{array}{l}-0.2544 \\
(0.0775)\end{array}$ & $* * *$ & $\begin{array}{l}-0.0112 \\
(0.0244)\end{array}$ & $\begin{array}{r}0.1785 \\
(0.0401)\end{array}$ & $\begin{array}{l}-0.0988 \\
(0.0305)\end{array}$ \\
\hline Tajik & $\begin{array}{l}-0.1148 \\
(0.0440)\end{array}$ & $* * *$ & $\begin{array}{r}0.0009 \\
(0.0669)\end{array}$ & & $\begin{array}{l}-0.1870 \\
(0.0578)\end{array}$ & $* * *$ & $\begin{array}{l}-0.0444 \\
(0.0169)\end{array}$ & $\begin{array}{r}0.0003 \\
(0.0194)\end{array}$ & $\begin{array}{l}-0.0719 \\
(0.0224)\end{array}$ \\
\hline RegionD3 & $\begin{array}{r}0.2334 \\
(0.0495)\end{array}$ & $* * *$ & $\begin{array}{l}-0.1999 \\
(0.0785)\end{array}$ & $* *$ & $\begin{array}{r}0.6245 \\
(0.0667)\end{array}$ & $* * *$ & $\begin{array}{r}0.0901 \\
(0.0189)\end{array}$ & $\begin{array}{l}-0.0587 \\
(0.0232)\end{array}$ & $\begin{array}{r}0.2380 \\
(0.0249)\end{array}$ \\
\hline RegionD4 & $\begin{array}{r}0.0951 \\
(0.0515)\end{array}$ & $*$ & $\begin{array}{r}0.0758 \\
(0.0884)\end{array}$ & & $\begin{array}{r}0.1451 \\
(0.0714)\end{array}$ & $* *$ & $\begin{array}{r}0.0368 \\
(0.0198)\end{array}$ & $\begin{array}{r}0.0217 \\
(0.0250)\end{array}$ & $\begin{array}{r}0.0557 \\
(0.0275)\end{array}$ \\
\hline RegionD5 & $\begin{array}{l}-0.1089 \\
(0.0613)\end{array}$ & * & $\begin{array}{l}-0.4645 \\
(0.0930)\end{array}$ & $* * *$ & $\begin{array}{r}0.1750 \\
(0.0827)\end{array}$ & $* *$ & $\begin{array}{l}-0.0428 \\
(0.0242)\end{array}$ & $\begin{array}{l}-0.1556 \\
(0.0340)\end{array}$ & $\begin{array}{r}0.0679 \\
(0.0325)\end{array}$ \\
\hline HHSize & $\begin{array}{l}-0.0099 \\
(0.0117)\end{array}$ & & $\begin{array}{l}-0.0297 \\
(0.0191)\end{array}$ & & $\begin{array}{l}-0.0054 \\
(0.0152)\end{array}$ & & $\begin{array}{l}-0.0039 \\
(0.0045)\end{array}$ & $\begin{array}{l}-0.0086 \\
(0.0056)\end{array}$ & $\begin{array}{l}-0.0020 \\
(0.0058)\end{array}$ \\
\hline Child6 & $\begin{array}{l}-0.0399 \\
(0.0250)\end{array}$ & & $\begin{array}{l}-0.0023 \\
(0.0404)\end{array}$ & & $\begin{array}{l}-0.0638 \\
(0.0331)\end{array}$ & $*$ & $\begin{array}{l}-0.0155 \\
(0.0097)\end{array}$ & $\begin{array}{l}-0.0007 \\
(0.0117)\end{array}$ & $\begin{array}{l}-0.0243 \\
(0.0126)\end{array}$ \\
\hline Child6_18 & $\begin{array}{r}0.0359 \\
(0.0190)\end{array}$ & $*$ & $\begin{array}{r}0.0484 \\
(0.0304)\end{array}$ & & $\begin{array}{r}0.0397 \\
(0.0249)\end{array}$ & & $\begin{array}{r}0.0140 \\
(0.0074)\end{array}$ & $\begin{array}{r}0.0140 \\
(0.0088)\end{array}$ & $\begin{array}{r}0.0151 \\
(0.0095)\end{array}$ \\
\hline Elder65 & $\begin{array}{r}0.0051 \\
(0.0329)\end{array}$ & & $\begin{array}{r}0.0151 \\
(0.0536)\end{array}$ & & $\begin{array}{r}0.0049 \\
(0.0443)\end{array}$ & & $\begin{array}{r}0.0020 \\
(0.0128)\end{array}$ & $\begin{array}{r}0.0044 \\
(0.0155)\end{array}$ & $\begin{array}{r}0.0018 \\
(0.0168)\end{array}$ \\
\hline Mig_HH & $\begin{array}{l}-0.1445 \\
(0.0517)\end{array}$ & $* * *$ & $\begin{array}{l}-0.2160 \\
(0.0852)\end{array}$ & $* *$ & $\begin{array}{l}-0.0886 \\
(0.0672)\end{array}$ & & $\begin{array}{l}-0.0567 \\
(0.0204)\end{array}$ & $\begin{array}{l}-0.0666 \\
(0.0277)\end{array}$ & $\begin{array}{l}-0.0334 \\
(0.0251)\end{array}$ \\
\hline OtherIncome1000 & $\begin{array}{r}0.0479 \\
(0.0226)\end{array}$ & $* *$ & $\begin{array}{r}0.1458 \\
(0.0502)\end{array}$ & $* * *$ & $\begin{array}{r}0.0199 \\
(0.0309)\end{array}$ & & $\begin{array}{r}0.0186 \\
(0.0088)\end{array}$ & $\begin{array}{r}0.0422 \\
(0.0144)\end{array}$ & $\begin{array}{r}0.0076 \\
(0.0118)\end{array}$ \\
\hline Constant & $\begin{array}{r}0.5288 \\
(0.1169) \\
\end{array}$ & $* * *$ & $\begin{array}{r}0.2974 \\
(0.1755) \\
\end{array}$ & $*$ & $\begin{array}{r}-0.4345 \\
(0.1353) \\
\end{array}$ & $* * *$ & & & \\
\hline $\begin{array}{l}\mathrm{N} \\
\text { Pseudo R2 }\end{array}$ & $\begin{array}{r}6,926 \\
0.1520\end{array}$ & & $\begin{array}{r}3,244 \\
0.0638\end{array}$ & & $\begin{array}{r}3,682 \\
0.0819\end{array}$ & & & & \\
\hline
\end{tabular}


Table 7. Probit Estimates and Marginal Effects: Urban Sample and by Gender (Dependent variable: worked in last 14 days, $L F P$ )

\begin{tabular}{|c|c|c|c|c|c|c|c|c|c|}
\hline \multirow{3}{*}{$\begin{array}{l}\text { Variables } \\
\text { Age30_34 }\end{array}$} & \multicolumn{6}{|c|}{ Probit Estimates } & \multicolumn{3}{|c|}{ Marginal Effects } \\
\hline & \multicolumn{2}{|c|}{ All } & \multicolumn{2}{|c|}{ Men } & \multicolumn{2}{|c|}{ Women } & \multirow{2}{*}{$\begin{array}{c}\text { All } \\
0.0638 \\
(0.0384)\end{array}$} & \multirow{2}{*}{$\begin{array}{c}\text { Men } \\
0.0178 \\
(0.0461)\end{array}$} & \multirow{2}{*}{$\begin{array}{r}\text { Women } \\
0.0473 \\
(0.0520)\end{array}$} \\
\hline & $\begin{array}{r}0.1626 \\
(0.0988)\end{array}$ & * & $\begin{array}{r}0.0614 \\
(0.1619)\end{array}$ & & $\begin{array}{r}0.1305 \\
(0.1415)\end{array}$ & & & & \\
\hline Age35_39 & $\begin{array}{r}0.2913 \\
0.1097)\end{array}$ & $* * *$ & -0.0070 & & $\begin{array}{r}0.3419 \\
(0.1493)\end{array}$ & $* *$ & 0.1131 & $\begin{array}{l}-0.0021 \\
(0.0546)\end{array}$ & 0.1268 \\
\hline Age40_44 & $\begin{array}{r}0.2509 \\
(0.1150)\end{array}$ & $* *$ & $\begin{array}{l}-0.2122 \\
(0.1870)\end{array}$ & & $\begin{array}{r}0.4358 \\
(0.1494)\end{array}$ & $* * *$ & $\begin{array}{r}0.0976 \\
(0.0436)\end{array}$ & $\begin{array}{c}-0.0658 \\
(0.0609)\end{array}$ & $\begin{array}{r}0.1642 \\
(0.0582)\end{array}$ \\
\hline Age45_49 & $\begin{array}{r}0.2800 \\
(0.1203)\end{array}$ & $* *$ & $\begin{array}{l}-0.1635 \\
(0.1971)\end{array}$ & & $\begin{array}{r}0.4808 \\
(0.1590)\end{array}$ & $* * *$ & $\begin{array}{r}0.1085 \\
(0.0453)\end{array}$ & $\begin{array}{l}-0.0502 \\
(0.0630)\end{array}$ & $\begin{array}{r}0.1817 \\
(0.0621)\end{array}$ \\
\hline Age50_55 & $\begin{array}{l}-0.1179 \\
(0.1205)\end{array}$ & & $\begin{array}{l}-0.4252 \\
(0.1848)\end{array}$ & $* *$ & $\begin{array}{r}0.1427 \\
(0.1683)\end{array}$ & & $\begin{array}{c}-0.0468 \\
(0.0480)\end{array}$ & $\begin{array}{c}-0.1385 \\
(0.0653)\end{array}$ & $\begin{array}{r}0.0519 \\
(0.0625)\end{array}$ \\
\hline Mig_Exp & $\begin{array}{l}-0.5998 \\
(0.1657)\end{array}$ & $* * *$ & $\begin{array}{l}-0.7712 \\
(0.1607)\end{array}$ & $* * *$ & $\begin{array}{r}0.4351 \\
(0.4682)\end{array}$ & & $\begin{array}{l}-0.2332 \\
(0.0600)\end{array}$ & $\begin{array}{l}-0.2706 \\
(0.0622)\end{array}$ & $\begin{array}{r}0.1664 \\
(0.1864)\end{array}$ \\
\hline EducGen & $\begin{array}{r}0.2013 \\
(0.0930)\end{array}$ & $* *$ & $\begin{array}{r}0.4179 \\
(0.1767)\end{array}$ & $* *$ & $\begin{array}{r}0.0428 \\
(0.1129)\end{array}$ & & $\begin{array}{r}0.0795 \\
(0.0366)\end{array}$ & $\begin{array}{r}0.1190 \\
(0.0488)\end{array}$ & $\begin{array}{r}0.0152 \\
(0.0401)\end{array}$ \\
\hline EducVoc & $\begin{array}{r}0.6379 \\
(0.1070)\end{array}$ & $* * *$ & $\begin{array}{r}0.5212 \\
(0.1848)\end{array}$ & $* * *$ & $\begin{array}{r}0.7349 \\
(0.1372)\end{array}$ & $* * *$ & $\begin{array}{r}0.2379 \\
(0.0363)\end{array}$ & $\begin{array}{r}0.1351 \\
(0.0419)\end{array}$ & $\begin{array}{r}0.2799 \\
(0.0529)\end{array}$ \\
\hline EducHigh & $\begin{array}{r}0.8777 \\
(0.1078)\end{array}$ & $* * *$ & $\begin{array}{r}0.6700 \\
(0.1826)\end{array}$ & $* * *$ & $\begin{array}{r}1.0699 \\
(0.1374)\end{array}$ & $* * *$ & $\begin{array}{r}0.3156 \\
(0.0330)\end{array}$ & $\begin{array}{r}0.1719 \\
(0.0405)\end{array}$ & $\begin{array}{r}0.4061 \\
(0.0489)\end{array}$ \\
\hline Female & $\begin{array}{l}-1.0102 \\
(0.0775)\end{array}$ & $* * *$ & & & & & $\begin{array}{l}-0.3820 \\
(0.0268)\end{array}$ & & \\
\hline Head & $\begin{array}{r}0.3079 \\
(0.0913)\end{array}$ & $* * *$ & $\begin{array}{c}0.3251 \\
(0.1516)\end{array}$ & $* *$ & $\begin{array}{r}0.2977 \\
(0.1438)\end{array}$ & $* *$ & $\begin{array}{r}0.1204 \\
(0.0350)\end{array}$ & $\begin{array}{r}0.0962 \\
(0.0449)\end{array}$ & $\begin{array}{r}0.1108 \\
(0.0555)\end{array}$ \\
\hline Married & $\begin{array}{c}-0.0922 \\
(0.0908)\end{array}$ & & $\begin{array}{r}0.6158 \\
(0.1764)\end{array}$ & $* * *$ & $\begin{array}{l}-0.3455 \\
(0.1195)\end{array}$ & $* * *$ & $\begin{array}{l}-0.0363 \\
(0.0356)\end{array}$ & $\begin{array}{r}0.2118 \\
(0.0673)\end{array}$ & $\begin{array}{l}-0.1280 \\
(0.0456)\end{array}$ \\
\hline Tajik & $\begin{array}{c}-0.0366 \\
(0.0901)\end{array}$ & & $\begin{array}{r}0.0969 \\
(0.1424)\end{array}$ & & $\begin{array}{c}-0.1722 \\
(0.1178)\end{array}$ & & $\begin{array}{l}-0.0145 \\
(0.0355)\end{array}$ & $\begin{array}{r}0.0292 \\
(0.0440)\end{array}$ & $\begin{array}{l}-0.0628 \\
(0.0440)\end{array}$ \\
\hline RegionD2 & $\begin{array}{r}0.2993 \\
(0.0761)\end{array}$ & $* * *$ & $\begin{array}{r}0.0902 \\
(0.1201)\end{array}$ & & $\begin{array}{r}0.4486 \\
(0.0994)\end{array}$ & $* * *$ & $\begin{array}{r}0.1170 \\
(0.0290)\end{array}$ & $\begin{array}{r}0.0261 \\
(0.0341)\end{array}$ & $\begin{array}{r}0.1651 \\
(0.0380)\end{array}$ \\
\hline RegionD3 & $\begin{array}{r}0.0575 \\
(0.0817)\end{array}$ & & $\begin{array}{l}-0.0564 \\
(0.1237)\end{array}$ & & $\begin{array}{r}0.1386 \\
(0.1137)\end{array}$ & & $\begin{array}{r}0.0227 \\
(0.0322)\end{array}$ & $\begin{array}{l}-0.0167 \\
(0.0372)\end{array}$ & $\begin{array}{r}0.0501 \\
(0.0419)\end{array}$ \\
\hline RegionD4 & $\begin{array}{r}0.1372 \\
(0.0928)\end{array}$ & & $\begin{array}{r}0.1516 \\
(0.1567)\end{array}$ & & $\begin{array}{r}0.0994 \\
(0.1267)\end{array}$ & & $\begin{array}{r}0.0539 \\
(0.0360)\end{array}$ & $\begin{array}{r}0.0424 \\
(0.0415)\end{array}$ & $\begin{array}{r}0.0360 \\
(0.0466)\end{array}$ \\
\hline RegionD5 & $\begin{array}{l}-0.0628 \\
(0.1172)\end{array}$ & & $\begin{array}{l}-0.5941 \\
(0.1585)\end{array}$ & $* * *$ & $\begin{array}{r}0.4255 \\
(0.1529)\end{array}$ & $* * *$ & $\begin{array}{c}-0.0249 \\
(0.0466)\end{array}$ & $\begin{array}{l}-0.2073 \\
(0.0615)\end{array}$ & $\begin{array}{r}0.1624 \\
(0.0607)\end{array}$ \\
\hline HHSize & $\begin{array}{r}0.0271 \\
(0.0192)\end{array}$ & & $\begin{array}{l}-0.0337 \\
(0.0319)\end{array}$ & & $\begin{array}{r}0.0495 \\
(0.0254)\end{array}$ & $*$ & $\begin{array}{r}0.0107 \\
(0.0076)\end{array}$ & $\begin{array}{c}-0.0099 \\
(0.0094)\end{array}$ & $\begin{array}{r}0.0176 \\
(0.0091)\end{array}$ \\
\hline Child6 & $\begin{array}{c}-0.0886 \\
(0.0408)\end{array}$ & $* *$ & $\begin{array}{r}0.0617 \\
(0.0608)\end{array}$ & & $\begin{array}{l}-0.1993 \\
(0.0586)\end{array}$ & $* * *$ & $\begin{array}{l}-0.0351 \\
(0.0161)\end{array}$ & $\begin{array}{r}0.0181 \\
(0.0179)\end{array}$ & $\begin{array}{l}-0.0709 \\
(0.0207)\end{array}$ \\
\hline Child6_18 & $\begin{array}{l}-0.0406 \\
(0.0318)\end{array}$ & & $\begin{array}{r}0.0282 \\
(0.0516)\end{array}$ & & $\begin{array}{c}-0.0245 \\
(0.0420)\end{array}$ & & $\begin{array}{l}-0.0161 \\
(0.0126)\end{array}$ & $\begin{array}{r}0.0083 \\
(0.0152)\end{array}$ & $\begin{array}{l}-0.0087 \\
(0.0149)\end{array}$ \\
\hline Elder65 & $\begin{array}{c}-0.0803 \\
(0.0657)\end{array}$ & & $\begin{array}{r}0.0473 \\
(0.1067)\end{array}$ & & $\begin{array}{l}-0.1693 \\
(0.0935)\end{array}$ & $*$ & $\begin{array}{l}-0.0318 \\
(0.0260)\end{array}$ & $\begin{array}{r}0.0139 \\
(0.0313)\end{array}$ & $\begin{array}{c}-0.0602 \\
(0.0334)\end{array}$ \\
\hline Mig_HH & $\begin{array}{l}-0.0165 \\
(0.0961)\end{array}$ & & $\begin{array}{l}-0.0849 \\
(0.1578)\end{array}$ & & $\begin{array}{l}-0.0099 \\
(0.1290)\end{array}$ & & $\begin{array}{l}-0.0065 \\
(0.0381)\end{array}$ & $\begin{array}{l}-0.0256 \\
(0.0489)\end{array}$ & $\begin{array}{l}-0.0035 \\
(0.0457)\end{array}$ \\
\hline OtherIncome1000 & $\begin{array}{r}0.0348 \\
(0.0540)\end{array}$ & & $\begin{array}{r}0.0726 \\
(0.1124)\end{array}$ & & $\begin{array}{r}0.0067 \\
(0.0659)\end{array}$ & & $\begin{array}{r}0.0138 \\
(0.0214)\end{array}$ & $\begin{array}{r}0.0213 \\
(0.0330)\end{array}$ & $\begin{array}{r}0.0024 \\
(0.0234)\end{array}$ \\
\hline Constant & $\begin{array}{r}0.0592 \\
(0.1884)\end{array}$ & & $\begin{array}{r}-0.2652 \\
(0.2794)\end{array}$ & & $\begin{array}{c}-0.8157 \\
(0.2192)\end{array}$ & $* * *$ & & & \\
\hline $\begin{array}{l}\mathrm{N} \\
\text { Pseundo R2 }\end{array}$ & $\begin{array}{r}3,17 \\
0207\end{array}$ & & $\begin{array}{r}1,41 \\
0,08 f\end{array}$ & & $\begin{array}{r}1,75 \\
013 c\end{array}$ & & & & \\
\hline
\end{tabular}


Table 8. Decomposing Gender Gap of 39.71\% in Labour Force Participation (Whole Sample)

\begin{tabular}{|c|c|c|c|c|c|c|}
\hline & \multicolumn{3}{|c|}{ Characteristics Effect } & \multicolumn{3}{|c|}{ Coefficients Effect } \\
\hline & Est. & Share & & Est. & Share & \\
\hline Overall & 0.0362 & 9.12 & $* * *$ & 0.3609 & 90.88 & $* * *$ \\
\hline Excluding Constant & 0.0362 & 9.12 & $* * *$ & 0.3282 & 82.66 & $* * *$ \\
\hline Age & 0.0011 & 0.28 & $* *$ & 0.0091 & 2.28 & $* *$ \\
\hline Age25_29 & 0.0000 & 0.00 & & 0.0144 & 3.64 & $*$ \\
\hline Age30_34 & 0.0004 & 0.11 & & 0.0120 & 3.02 & $* *$ \\
\hline Age35_39 & -0.0001 & -0.02 & & -0.0066 & -1.67 & \\
\hline Age40_44 & 0.0000 & 0.00 & & -0.0066 & -1.67 & \\
\hline Age45_49 & 0.0000 & 0.00 & & -0.0007 & -0.16 & \\
\hline Age50_55 & 0.0007 & 0.17 & $* *$ & -0.0034 & -0.87 & \\
\hline Mig_Exp^ ${ }^{\wedge}$ & -0.0164 & -4.13 & $* * *$ & 0.1178 & 29.66 & $* *$ \\
\hline Mig_Exp_c & -0.0082 & -2.07 & $* * *$ & 0.1186 & 29.87 & $* *$ \\
\hline Mig_Exp & -0.0082 & -2.07 & $* * *$ & -0.0008 & -0.21 & $* *$ \\
\hline Education & 0.0138 & 3.46 & $* * *$ & 0.0896 & 22.57 & $* * *$ \\
\hline EducPrimary & 0.0062 & 1.55 & $* * *$ & 0.0218 & 5.48 & $* * *$ \\
\hline EducGen & 0.0011 & 0.28 & & 0.0816 & 20.56 & $* * *$ \\
\hline EducVoc & 0.0003 & 0.07 & & -0.0049 & -1.24 & $* *$ \\
\hline EducHigh & 0.0062 & 1.56 & $* * *$ & -0.0088 & -2.23 & $* * *$ \\
\hline $\operatorname{Head}^{\wedge}$ & 0.0302 & 7.60 & $* * *$ & 0.0094 & 2.37 & \\
\hline Head_c & 0.0151 & 3.80 & $* * *$ & 0.0101 & 2.53 & \\
\hline Head & 0.0151 & 3.80 & $* * *$ & -0.0006 & -0.16 & \\
\hline Married^ & 0.0126 & 3.18 & $* * *$ & 0.0955 & 24.04 & $* * *$ \\
\hline Married_c & 0.0063 & 1.59 & $* * *$ & -0.0228 & -5.73 & $* * *$ \\
\hline Married & 0.0063 & 1.59 & $* * *$ & 0.1182 & 29.77 & $* * *$ \\
\hline Tajik^ & 0.0000 & -0.01 & & 0.0202 & 5.08 & $* * *$ \\
\hline Tajik_c & 0.0000 & 0.00 & & -0.0096 & -2.41 & $* * *$ \\
\hline Tajik & 0.0000 & 0.00 & & 0.0297 & 7.49 & $* * *$ \\
\hline Urban^ & 0.0004 & 0.09 & $*$ & -0.0097 & -2.45 & \\
\hline Rural & 0.0002 & 0.05 & $*$ & -0.0144 & -3.62 & \\
\hline Urban & 0.0002 & 0.05 & $*$ & 0.0047 & 1.17 & \\
\hline Region & -0.0002 & -0.06 & & -0.0019 & -0.49 & \\
\hline RegionD1 & -0.0002 & -0.05 & & 0.0085 & 2.15 & $* * *$ \\
\hline RegionD2 & 0.0002 & 0.06 & $* * *$ & 0.0234 & 5.90 & $* * *$ \\
\hline RegionD3 & -0.0002 & -0.05 & & -0.0526 & -13.24 & $* * *$ \\
\hline RegionD4 & -0.0004 & -0.10 & $* * *$ & 0.0226 & 5.70 & $* * *$ \\
\hline RegionD5 & 0.0003 & 0.08 & $* * *$ & -0.0040 & -1.00 & $* * *$ \\
\hline Household Composition & -0.0026 & -0.65 & $* *$ & -0.0424 & -10.68 & \\
\hline HHSize & -0.0020 & -0.51 & $*$ & -0.1060 & -26.70 & $*$ \\
\hline Child6 & 0.0002 & 0.06 & & 0.0487 & 12.26 & $* *$ \\
\hline Child6_18 & -0.0009 & -0.23 & & 0.0099 & 2.50 & \\
\hline Elder65 & 0.0001 & 0.03 & & 0.0050 & 1.27 & \\
\hline Mig_HH^ & 0.0025 & 0.63 & $* *$ & 0.0141 & 3.55 & \\
\hline Mig_HH_c & 0.0013 & 0.32 & $* *$ & 0.0171 & 4.32 & \\
\hline Mig_HH & 0.0013 & 0.32 & $* *$ & -0.0031 & -0.77 & \\
\hline OtherIncome1000 & -0.0051 & -1.29 & $* * *$ & 0.0267 & 6.73 & $* *$ \\
\hline Constant & & & & 0.0326 & 8.22 & \\
\hline
\end{tabular}

Note: ^ indicates that the subgroup is based on binary variable and its complementary group. A variable ending with _c is a complementary group, such as Mig_Exp_c $=1-$ Mig_Exp. Share is the percentage that element is contributing to the gender gap of $39.71 \%$. 
Table 9. Decomposing Gender Gap of $38.72 \%$ in Labour Force Participation (Rural Sample)

\begin{tabular}{|c|c|c|c|c|c|c|}
\hline & \multicolumn{3}{|c|}{ Characteristics Effect } & \multicolumn{3}{|c|}{ Coefficients Effect } \\
\hline & Est. & Share & & Est. & Share & \\
\hline Overall & 0.0253 & 6.53 & $* *$ & 0.3619 & 93.47 & $* * *$ \\
\hline Excluding Constant & 0.0253 & 6.53 & $* *$ & 0.3285 & 84.85 & $* * *$ \\
\hline Age & 0.0010 & 0.25 & & 0.0065 & 1.67 & \\
\hline Age25_29 & 0.0000 & 0.00 & & 0.0104 & 2.69 & \\
\hline Age30_34 & 0.0003 & 0.07 & & 0.0087 & 2.24 & \\
\hline Age35_39 & 0.0000 & 0.00 & & -0.0100 & -2.58 & $* *$ \\
\hline Age40_44 & -0.0001 & -0.02 & & -0.0056 & -1.44 & \\
\hline Age45_49 & 0.0001 & 0.01 & & 0.0027 & 0.70 & \\
\hline Age50_55 & 0.0007 & 0.17 & & 0.0003 & 0.07 & \\
\hline Mig_Exp^ ${ }^{\wedge}$ & -0.0155 & -3.99 & $* * *$ & 0.0888 & 22.94 & $*$ \\
\hline Mig_Exp_c & -0.0077 & -2.00 & $* * *$ & 0.0894 & 23.10 & $*$ \\
\hline Mig_Exp & -0.0077 & -2.00 & $* * *$ & -0.0006 & -0.16 & $*$ \\
\hline Education & 0.0096 & 2.49 & $*$ & 0.0961 & 24.81 & $* * *$ \\
\hline EducPrimary & 0.0041 & 1.06 & & 0.0259 & 6.68 & $* * *$ \\
\hline EducGen & 0.0014 & 0.35 & & 0.0782 & 20.21 & $* * *$ \\
\hline EducVoc & -0.0007 & -0.19 & & -0.0023 & -0.60 & \\
\hline EducHigh & 0.0049 & 1.27 & $* *$ & -0.0057 & -1.47 & $* * *$ \\
\hline $\mathrm{Head}^{\wedge}$ & 0.0242 & 6.26 & $* *$ & 0.0133 & 3.42 & \\
\hline Head_c & 0.0121 & 3.13 & $* *$ & 0.0139 & 3.58 & \\
\hline Head & 0.0121 & 3.13 & $* *$ & -0.0006 & -0.16 & \\
\hline Married $\wedge$ & 0.0103 & 2.67 & $* * *$ & 0.0981 & 25.33 & $* * *$ \\
\hline Married_c & 0.0052 & 1.34 & $* * *$ & -0.0211 & -5.45 & $* * *$ \\
\hline Married & 0.0052 & 1.34 & $* * *$ & 0.1192 & 30.78 & $* * *$ \\
\hline Tajik^ & 0.0000 & 0.00 & & 0.0154 & 3.99 & $* *$ \\
\hline Tajik_c & 0.0000 & 0.00 & & -0.0090 & -2.33 & $* *$ \\
\hline Tajik & 0.0000 & 0.00 & & 0.0245 & 6.32 & $* *$ \\
\hline Region & -0.0001 & -0.03 & & 0.0049 & 1.26 & \\
\hline RegionD2 & 0.0001 & 0.02 & $* * *$ & 0.0399 & 10.30 & $* * *$ \\
\hline RegionD3 & -0.0001 & -0.04 & & -0.0627 & -16.20 & $* * *$ \\
\hline RegionD4 & -0.0004 & -0.12 & $* * *$ & 0.0309 & 7.97 & $* * *$ \\
\hline RegionD5 & 0.0004 & 0.11 & $* * *$ & -0.0031 & -0.81 & $* * *$ \\
\hline Household Composition & -0.0027 & -0.70 & $* *$ & -0.0371 & -9.59 & \\
\hline HHSize & -0.0017 & -0.43 & & -0.0769 & -19.87 & \\
\hline Child6 & 0.0000 & -0.01 & & 0.0309 & 7.98 & \\
\hline Child6_18 & -0.0011 & -0.29 & & 0.0075 & 1.95 & \\
\hline Elder65 & 0.0001 & 0.03 & & 0.0014 & 0.36 & \\
\hline$M i g \_H H^{\wedge}$ & 0.0031 & 0.81 & $* *$ & 0.0150 & 3.87 & \\
\hline Mig_HH_c & 0.0016 & 0.40 & $* *$ & 0.0189 & 4.87 & \\
\hline Mig_HH & 0.0016 & 0.40 & $* *$ & -0.0039 & -1.00 & \\
\hline OtherIncome1000 & -0.0047 & -1.22 & $* * *$ & 0.0276 & 7.14 & $* *$ \\
\hline Constant & & & & 0.0334 & 8.62 & \\
\hline
\end{tabular}

Note: $\wedge$ indicates that the subgroup is based on binary variable and its complementary group. A variable ending with _c is a complementary group, such as Mig_Exp_c $=1-$ Mig_Exp. Share is the percentage that element is contributing to the gender gap of $38.72 \%$. 
Table 10. Decomposing Gender Gap of $42.72 \%$ in Labour Force Participation (Urban Sample)

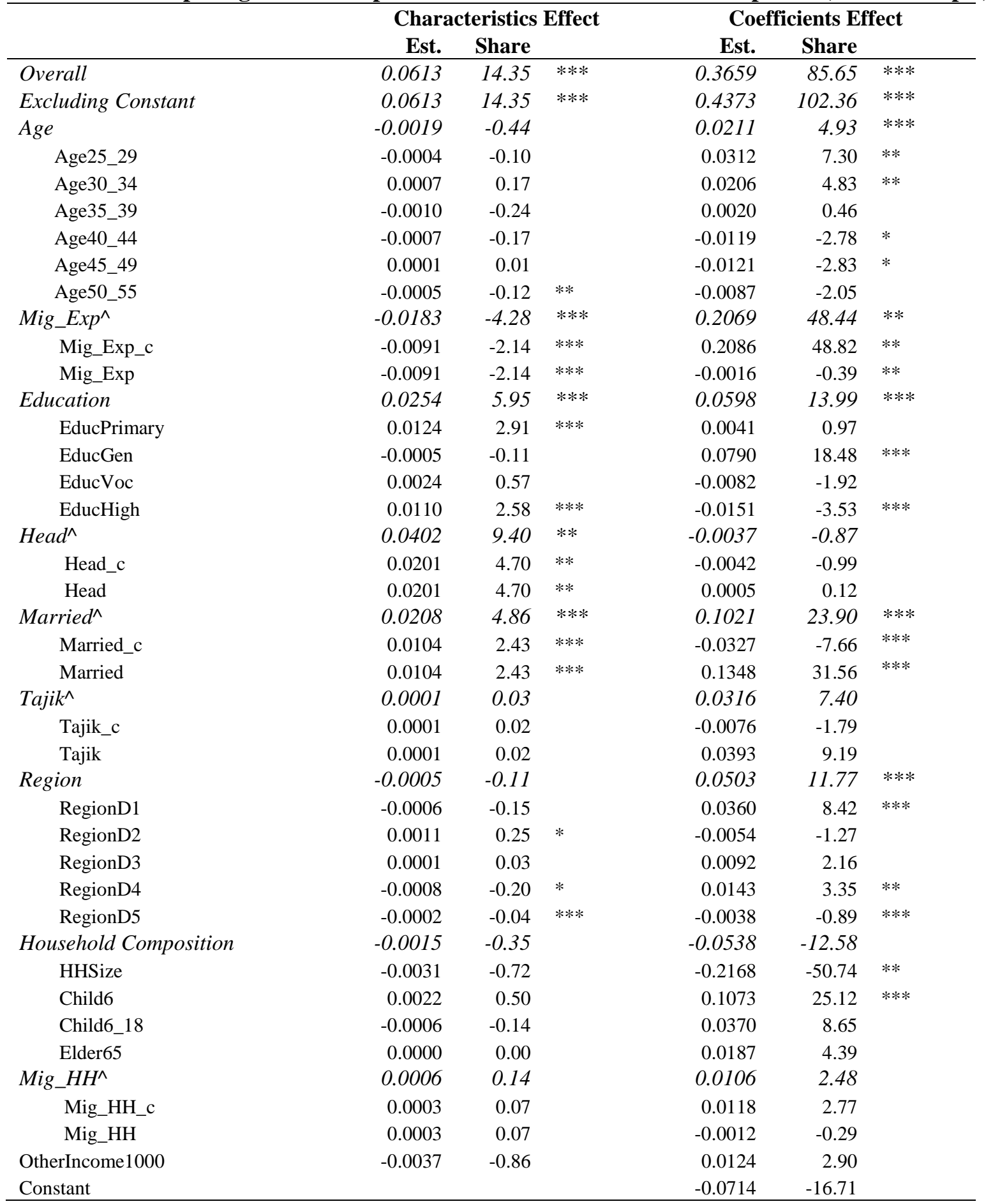

Note: $\wedge$ indicates that the subgroup is based on binary variable and its complementary group. A variable ending with _c is a complementary group, such as Mig_Exp_c $=1-$ Mig_Exp. Share is the percentage that element is contributing to the gender gap of $42.72 \%$. 
Table Appendix. Bivariate Probit Estimates: Labour Force Participation and Migration

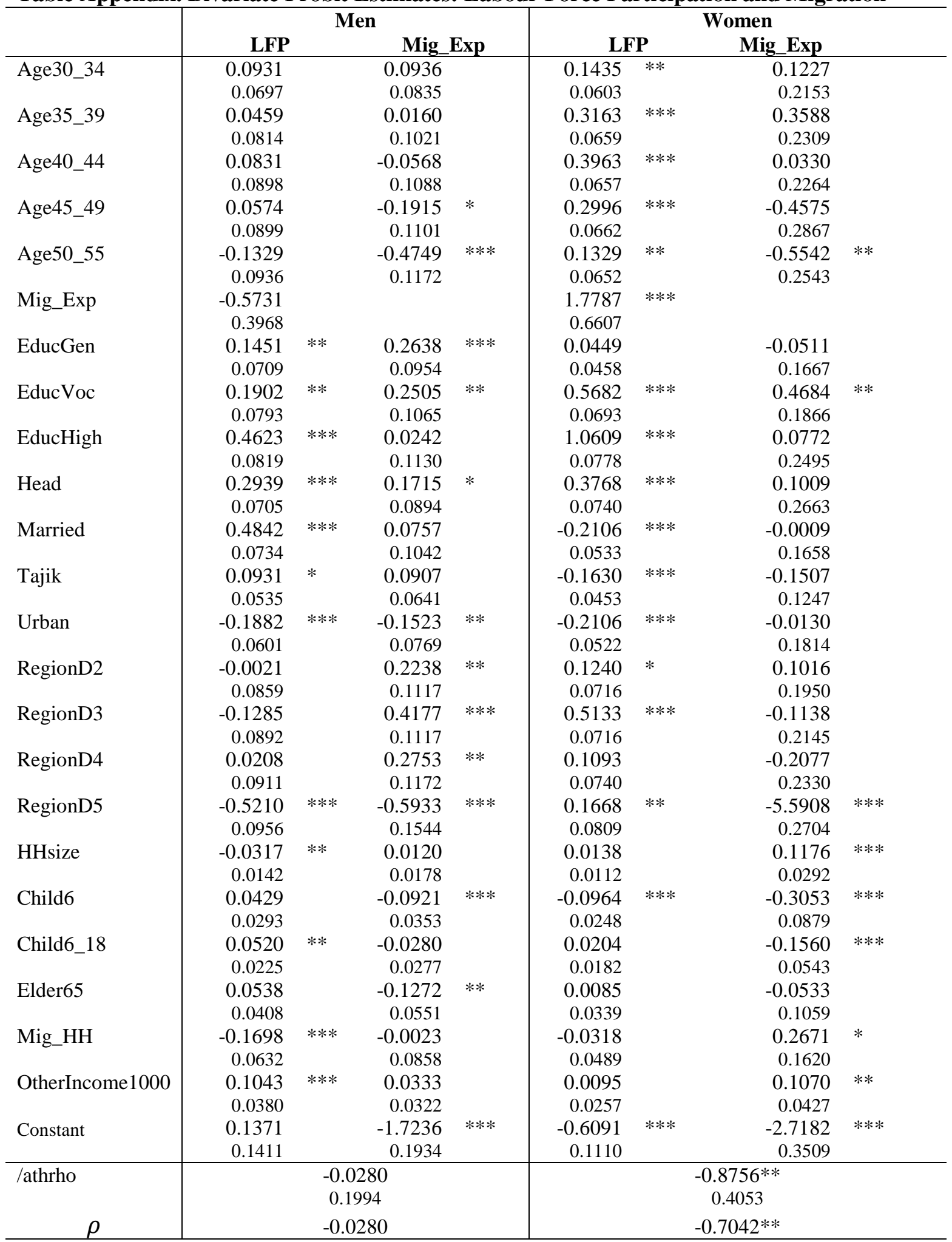

Note: /athrho is defined as $0.5 \ln ((1+\rho) /(1-\rho))$, where $\rho$ is the correlation coefficient of error terms in two equations of LFP and Mig_Exp. Wald test for $\rho=0$ is not significant at $10 \%$ level for men, and significant at $5 \%$ level for women. 